\title{
О КАЧЕСТВЕ ФЕДЕРАЛЬНОГО СТАТИСТИЧЕСКОГО НАБЛЮДЕНИЯ ЗА МИГРАЦИОННЫМИ ПРОЦЕССАМИ
}

\author{
ОЛЬГА ЧУДИНОВСКИХ, АНАСТАСИЯ СТЕПАНОВА
}

\begin{abstract}
В статье рассматриваются основные проблемы, присущчие методологии текущего учета миграции, которую Росстат начал применять с 2011 2. В исторической ретроспективе дается описание изменений методологии текущего учета в постсоветский период, их причин и возможного влияния на объемы и структуру потоков. Подробно рассматривается ситуация, сложившаяся в российской статистике миграционных потоков в последние годы, когда статистика начала учитывать 6 качестве мигрантов не только лии, зарегистрированньх по месту жительства, но и тех, кто зарегистрировался по месту пребывания на срок 9 месяцев и более. Изменение критериев учета заметно повлияло на динамику показателей международной и внутренней миграции. Выросли объемы регистрируемой миграции, изменились структурные характеристики потоков, в первую очередь по направлениям миграции и гражданству мигрантов. Основное внимание в статье уделено статистике международной миграции, так как последствия использования новых принципов сбора данных в этом сегменте проявились наиболее ярко. Делается вывод, что в основу современной методологии учета заложен ряд спорных допущений, правомерность которых не проверялась эмпирически. В качестве возможного временного решения предлагается наладить взаимодействие Росстата с органами по вопросам миграчии с иелью проведения совместных выборочных разработок имеющихся у ГУВМ МВД данных для проверки их надежности и оченки масштабов погрешностей, которые может вызывать применение существующей методологии учета миграции.
\end{abstract}

Ключевые слова: текущций учет миграции, регистрация по месту жительства и месту пребывания, статистика миграциии, гражданство.

\section{ВВЕДЕНИЕ}

В 2012 г. Росстат опубликовал очередной бюллетень «Численность и миграция населения Российской Федерации в 2011 году» (Росстат 2012). Данные за 2011 г. показали почти двукратный рост показателей международной и внутренней миграции по сравнению с предыдущим годом (таблица 1). Вначале это стремительное увеличение коснулось только числа прибытий. Число же выбытий столь же стремительно увеличилось, начиная с 2012 г., когда оно достигло уровня, наблюдавшегося в России только в 1990-е годы. Если говорить о международной миграции, то изменились не только общие объемы потоков, но и их структура. Доля иностранцев в потоках прибывших, не превышавшая в начале 2000 -х $10 \%$ потока, начиная с 2011 г. выросла до 70\% и более. С 2011 г. и до начала массовой вынужденной миграции с Украины в 2014 г. мигранты прибывали преимущественно из Узбекистана, который также стал главной страной назначения для «эмигрантов» из России. Почему мы пишем слово «эмигрант» в кавычках, и что стало причиной таких стремительных и существенных перемен?

ОЛЬГА СЕРГЕЕВНА ЧУДИНОВСКИХ (migrstat@yandex.ru), МОСКОВСКИЙ ГОСУДАРСТВЕННЫЙ УНИВЕРСИТЕТ имеНИ М.В. ЛОмОНОСОВА, Россия.

АНАСТАСИЯ ВИКТоРОВНА СТЕПАНОВА (stepanova.anastasia@gmail.com), МОСКОВСКИЙ ГОСУДАРСТВЕННЫЙ УНИвЕРСИТЕТ ИМЕНИ М.В. ЛОМОНОСОВА, РОССИЯ.

СТАТЬЯ ПОСТУПИЛА В РЕДАКЦИЮ В ЯНВАРЕ 2020 Г. 
В 2011 и 2012 гг. не было внезапно возникших обстоятельств как внутри России, так и за ее пределами, способных настолько сильно повлиять на масштабы и структуру миграции. Перечисленные изменения были связаны с переходом Росстата на новую методологию учета. Эта статья посвящена современной методологии текущего учета прибывших и выбывших и оценке её влияния на качество отечественной статистики миграции. В рамках данной работы мы не предполагаем анализ собственно трендов и структуры миграции. Описание данных в основном приводится в качестве иллюстрации того, как изменение методологии их сбора влияло на статистические показатели. Основное внимание будет уделено статистике международной миграции, поскольку в этом сегменте некоторые особенности новой методологии учета проявили себя наиболее ярко.

\section{ИСТОРИЯ ИЗМЕНЕНИЯ МЕТОДОЛОГИИ В ПОСТСОВЕТСКИЙ ПЕРИОД}

Можно сказать, что практически вся история колебаний показателей текущего учета миграции в постсоветское время связана с тем, что из-за намеренных или вынужденных изменений методологии сбора данных эти показатели менялись даже чаще, чем из-за реально действующих факторов выталкивания или притяжения. Такие изменения неизбежно оказывали влияние на полноту данных, их структуру по отдельным переменным и качество статистики в целом. К сожалению, характер этого влияния не всегда можно оценить в точном количественном выражении. Но факт влияния методологии на показатели отечественной статистики всегда следует принимать во внимание при работе с данными Росстата, впрочем, как и любой статистики, связанной с учетом миграции.

В таблице 1 приведены данные о потоках международной и внутрироссийской миграции с 1992 по 2018 г. В первой половине 1990-х на величину показателей влияли два обстоятельства. Во-первых, это был период массовой миграции в Россию из стран бывшего СССР и столь же значительной эмиграции из России представителей отдельных этнических групп и членов их семей как в страны дальнего зарубежья, так и в бывшие союзные республики. Во-вторых, большую роль играла методология сбора данных. Согласно правилам текущего учета миграции, листки (талоны) прибытия и убытия составлялись на лиц, прибывших к новому месту жительства ${ }^{1}$ на срок свыше полутора месяцев. Таким образом, статистика учитывала, например, командированных, лиц, прибывших на краткосрочные курсы и др. По истечении срока временной регистрации эти мигранты выписывались из места временного проживания и включались в статистику выбытий. Это увеличивало показатели миграционного оборота, который формировался не только за счет мигрантов, менявших место постоянного жительства, но и тех, кто приезжал на короткое время. Если на сальдо миграцииы это обстоятельство, возможно, и не оказывало большого влияния, то объемы потоков прибывших и выбывших оказывались завышенными. Отметим, что в отношении мигрантов, оформлявших (используя прежнюю

\footnotetext{
${ }^{1}$ Понятие «место пребывания» было введено Федеральным законом РФ от 25 июня 1993 г. №5242-I «О праве граждан Российской Федерации на свободу передвижения, выбор места пребывания и жительства в пределах Российской Федерации», но вплоть до 2011 г. оно не применялось в методологии учета миграции. 
терминологию) постоянную прописку, срок предположительного проживания уже не имел значения.

\section{Таблица 1. Общие итоги миграции населения в Российской Федерации, тыс. человек}

\begin{tabular}{lc|c|c}
\hline Год & $\begin{array}{c}\text { Прибывшие } \\
\text { из других мест России }\end{array}$ & $\begin{array}{c}\text { Прибывшие } \\
\text { из зарубежных стран }\end{array}$ & $\begin{array}{c}\text { Выбывшие } \\
\text { в зарубежные страны }\end{array}$ \\
\hline 1990 & 4263,1 & 913,2 & 729,5 \\
1991 & 3690,8 & 692,2 & 675,5 \\
1992 & 3266,8 & 926,0 & 673,1 \\
1993 & 2902,8 & 923,3 & 483,0 \\
1994 & 3017,0 & 1191,4 & 345,6 \\
1995 & 3130,3 & 866,9 & 347,3 \\
1996 & 2886,9 & 647,0 & 291,6 \\
1997 & 2724,9 & 597,7 & 233,0 \\
1998 & 2582,0 & 513,6 & 213,4 \\
1999 & 2477,0 & 379,7 & 215,0 \\
2000 & 2303,0 & 359,3 & 145,7 \\
2001 & 2140,6 & 193,5 & 121,2 \\
2002 & 2017,3 & 184,6 & 106,7 \\
2003 & 2039,0 & 129,1 & 94,0 \\
2004 & 1998,3 & 119,2 & 79,8 \\
2005 & 1911,4 & 177,2 & 69,8 \\
2006 & 1935,7 & 186,4 & 54,1 \\
2007 & 1998,0 & 287,0 & 47,0 \\
2008 & 1934,3 & 281,6 & 39,5 \\
2009 & 1707,7 & 279,9 & 32,5 \\
2010 & 1910,6 & 191,7 & 33,6 \\
2011 & 3058,5 & 356,5 & 36,8 \\
2012 & 3778,5 & 417,7 & 122,8 \\
2013 & 4014,6 & 482,2 & 186,4 \\
2014 & 4072,6 & 590,8 & 310,5 \\
2015 & 4135,9 & 598,6 & 353,2 \\
2016 & 4131,3 & 575,2 & 313,2 \\
2017 & 4184,5 & 589,0 & 377,2 \\
2018 & 4345,9 & 565,7 & 440,8 \\
\hline
\end{tabular}

Источник: Росстат. Общие итоги миграции населения (по потокам передвижения) URL: https://www.gks.ru/folder/12781 (дата обращения 02.02.2020).

Иными словами, существовали два так называемых критерия идентификации мигранта: временной - 45 и более дней пребывания ${ }^{2}$ для лиц с временной пропиской,

\footnotetext{
2 Такая практика, судя по имеющимся источникам, применялась с самого начала действия паспортной системы в СССР. В первом Положении о паспортной системе СССР (1932 г.) прямого указания на практику учета миграции на основании временной регистрации нет. Косвенно на статистический учет лиц, меняющих место временного проживания на короткие сроки, уже в начале действия паспортной системы (с 1932 г.) указывает В. Попов, отмечая, что статистические отрывные талоны к листку прибытия и выбытия составлялись на всех лиц, меняющих место пребывания, за исключением «дачников, отдыхающих в санаториях, домах отдыха, приезжающих в отпуска, на каникулы, экскурсантов, туристов, прибывающих на совещания, съезды и выбывающих обратно» (Попов 1996). В Положении о прописке и выписке населения в г. Москве 1964 г. указывалось, что «Прописка устанавливается постоянная и временная. Временно прописываются граждане, прибывшие на учебу, - на учебный год, в командировку - на срок командировки, но не свыше срока, установленного действующим законодательством, на лечение и в отпуск - на срок лечения и отпуска, в гости - на срок не свыше 45 суток, а также граждане, прибывшие по другим причинам, если временное проживание в городе Москве разрешено им органами милиции, - на срок не свыше одного
} 
и юридический - оформление постоянной прописки в новом месте проживания для тех, кто имел на нее право, без условий длительности фактического проживания. После распада СССР и до введения в 1996 г. новых правил регистрации учет краткосрочных мигрантов в большей степени оказывал влияние на показатели внутренней миграции.

Уменьшение потоков как внутренней, так и международной миграции в первой половине 1990-х (после пиковых значений 1994 г.) было связано с объективным трендом спадом вынужденной миграции из стран СНГ. Но не меньшее влияние, которое, как уже отмечалось, трудно оценить в количественном выражении, оказали и правила учета миграции. Новые правила регистрации населения по месту пребывания и месту жительства, принятые в 1995 г., уже не содержали требования учитывать для нужд статистики лиц, зарегистрированных на срок свыше полутора месяцев. Для целей статистического учета остался единственный критерий - юридический. Согласно Инструкции о применении правил регистрации и снятия граждан с регистрационного учета ${ }^{3}$ и Рекомендациям Госкомстата России по заполнению первичных документов статистического учета мигрантов ${ }^{4}$, листки учета составлялись только на лиц, зарегистрированных по месту жительства (в лексике советского периода - постоянной прописки). Сбор первичных данных для нужд Госкомстата о больших потоках мигрантов, которые регистрировались «по месту пребывания», в нормативных актах Госкомстата и МВД не упоминался 5 . Сначала срок временной регистрации предполагалось ограничить 180 днями, но вскоре эти рамки для граждан России были расширены до 5 лет, а нормативно-правовая база в отношении правового положения (и регистрации) мигрантов из стран СНГ, не имевших российского гражданства, в те годы еще не была создана. Начиная с 1996 г., когда новые правила регистрации вступили в силу, это решение привело к формированию значительных по численности потоков «условно-временных» мигрантов (и внутрироссийских, и международных), фактически сменивших место постоянного жительства, но не учтенных статистикой.

В отношении иностранных граждан листки прибытия заполнялись только при наличии у человека вида на жительство, дававшего право на «постоянную прописку», и эта практика преимущественно касалась граждан стран дальнего зарубежья. Вплоть до осени 2000 г. в отношении мигрантов из стран СНГ (а точнее - бывшего СССР) не существовало обязательного требования получения вида на жительство при переезде в Россию и до получения гражданства. В октябре 2000 г. вступил в силу новый порядок регистрации иностранных граждан по месту пребывания и месту жительства. Согласно новым правилам все без исключения граждане, подтвердившие или не

года» (Постановление Совмина СССР от 25 июня 1964 г. №585 «Об утверждении Положения о прописке и выписке населения в городе Москве»). Положение о паспортной системе СССР 1974 г. также содержало требование регистрации мигрантов, меняющих место пребывания на срок свыше 45 дней (Постановление Совмина СССР от 28 августа 1974 г. №677 «Об утверждении Положения о паспортной системе в СССР»).

${ }^{3}$ Инструкция о применении правил регистрации и снятия граждан с регистрационного учета по месту пребывания и по месту жительства в пределах Российской Федерации. Приложение 1 к Приказу МВД России от 23 октября 1995 г. №393.

${ }^{4}$ Госкомстат России (1995). Рекомендации по заполнению первичных документов статистического учета мигрантов (для территориальных паспортно-визовых служб МВД России).

${ }^{5}$ Безусловно, МВД вело учет временно зарегистрированных, но в этой статистике отражались процедуры, а не физические лица, сроки регистрации в отчетности не указывались. 
подтвердившие принадлежность к гражданству государств - членов СНГ, были обязаны получать в органах ОВИР вид на жительство, и только потом они получали право пройти регистрацию в паспортных столах. Такая система чрезвычайно затруднила и без того непростую процедуру получения регистрации. Это привело к заметному ухудшению показателей учтенной миграции уже с октября 2000 г. (Мкртчян 2003: 47-50).

Отметим, что в январе 2002 г. после длительных переговоров Росстата с Министерством внутренних дел было издано указание заместителя министра МВД (от 21 января 2002 г. №16/177), согласно которому на мигрантов, зарегистрированных по месту пребывания на срок 1 год и более, должны были составляться листки статистического учета (с указанием срока ожидаемого пребывания). Однако, как показала практика, далеко не все регионы, в частности Москва, следовали этому указанию. Цель Росстата не была достигнута, и полнота статистики оставалась очень спорной (Чудиновских 2009: 293-302). При обработке в Росстате первичных данных мигранты с постоянной и временной регистрацией не выделялись, поэтому оценить эффект от выполнения названного указания не представляется возможным. Как будет показано ниже, избирательное правоприменение на уровне регионов (и, по-видимому, отсутствие контроля со стороны центрального аппарата МВД) в те годы было распространенным явлением.

В 2002 г. был принят первый российский закон о правовом положении иностранных граждан, который ввел институт разрешений на временное проживание и определил основные статусы иностранцев в России. Однако вопросы сбора данных для нужд государственной статистики в новом законе не нашли отражения. Судя по всему, проект закона не проходил согласования с Госкомстатом. Это привело к парадоксальной ситуации: паспортно-визовые службы многих регионов, где, по-видимому, работали недостаточно опытные сотрудники, перестали составлять листки учета прибытий на иностранцев - ведь закон этого не требовал. В других регионах, где решения по этому вопросу принимали специалисты «старой школы», продолжали составлять листки и передавать их в территориальные органы статистики. Иными словами, при отсутствии правовых оснований решения о составлении листка статистического учета мигранта принимались на местах произвольно. Произошло непреднамеренное и негласное изменение методологии: в силу отсутствия правового основания иностранцы вообще не должны были попадать в статистический учет. Поскольку де-факто частично информация собиралась, нарушилось единообразие сбора данных по регионам России. По данным Росстата за 2003 г., в таких субъектах РФ как, например, г. Москва, Брянская, Липецкая, Смоленская и Нижегородская области, среди прибывших не было зарегистрировано ни одного иностранного гражданина. А в Татарстане, Ростовской, Челябинской, Саратовской и Белгородской областях число иностранцев среди прибывших превысило тысячу человек (Росстат 2004: таб. 2.24).

Всего, по данным Росстата, в потоке прибывших в 2003 г. число иностранцев и лиц без гражданства составило 20,4 тыс. В то же время, по данным ФМС России, в 2003 г. было выдано было выдано свыше 135 тыс. видов на жительство иностранцам и лицам без гражданства. Распределение международных мигрантов по гражданству показывает, 
что в первые годы наблюдения 6 доля иностранцев в потоках была невысока. В отдельные годы она не превышала 5-6\%. Складывалось впечатление, что в основном мигрируют («возвращаются») в Россию её же граждане, что нехарактерно для иммиграции. Конечно, можно предположить, что до 2003 г. часть иммигрантов действительно уже имели гражданство до прибытия в Россию: предоставление его в порядке регистрации через российские консульства было широко распространенной практикой в 1990-е - начале 2000-х. С 1992 по 2002 г. российское гражданство таким образом получили почти 1,7 млн жителей стран ближнего зарубежья. Впоследствии большинство из них переехали в Россию. Другие мигранты, вероятнее всего, получали гражданство после переезда в Россию по упрощенной схеме, т. е. в ускоренном порядке, который применялся (и применяется) в 99,9\% случаев.

Мы предполагаем, что, поскольку наличие российского гражданства существенно упрощает регистрацию по месту жительства, то в статистический учет недавние иммигранты попадали уже после получения российского паспорта (Чудиновских 2010: 816). В отношении владельцев видов на жительство во многих регионах сохранялась практика составления листков прибытия, но таких случаев было немного. Что касается разрешения на временное проживание (РВП), то, несмотря на долгосрочный статус таких мигрантов (РВП действует 3 года), по закону они могли быть зарегистрированы только по месту пребывания. Иными словами, сохранялась проблема не только полноты учета, но и обеспечения корректности данных о составе мигрантов по гражданству, в особенности в период с 2002 по 2006 г. включительно. А этот признак является одной из важнейших характеристик миграционных потоков. В 2006 г. был принят закон о миграционном учете, в котором, во-первых, лицам с РВП было разрешено регистрироваться по месту жительства, а во-вторых, было прямо сказано о передаче сведений в органы государственной статистики. Можно заметить (таблица 1), что это привело к некоторому увеличению объема потоков международной миграции, также выросла доля в них иностранцев и лиц без гражданства. Если в среднем в 2002-2006 гг. она не превышала 10\% среди прибывших, то в 2007-2010 гг. удельный вес иностранных граждан в потоках иммиграции вырос до $21 \%$.

Несмотря на положительные изменения, предусмотренные законом 2006 г., можно предположить, что новые правила с большой вероятностью могли привести и к повторному счету одних и тех же мигрантов. Такое предположение можно сделать, исходя из массового применения ускоренного приема в гражданство (в течение нескольких месяцев после прибытия) и необходимости повторной регистрации при изменении документа, удостоверяющего личность, в том числе при получении российского паспорта. Например, если иностранный гражданин с разрешением на временное проживание (которое давало право сразу обратиться за гражданством ${ }^{7}$ ) регистрировался по месту жительства,

\footnotetext{
${ }^{6}$ Росстат разрабатывает эту информацию с 2002 г.

7 До июля 2009 г. действовала часть 4 статьи 14 Закона о гражданстве, в соответствии с которой в упрощенном порядке приобрести его могли лица, имеющие РВП, и другие категории мигрантов, число которых было значительным. Вторым по распространенности основанием получения гражданства в этот период были международные соглашения России с Киргизией, Казахстаном и Белоруссией. В 2007-2009 гг., по данным ФМС России, по этим двум основаниям в гражданство были приняты 87\% всех иностранцев (61 
то статистика его учитывала как иностранца. Далее тот же человек в течение года получал российский паспорт, и это требовало новой регистрации. Поскольку процедуры для иностранцев и граждан России выполнялись разными подразделениями миграционных органов, а единой базы данных по гражданам России не существует до сих пор, велика вероятность, что и при второй регистрации на этого мигранта был еще раз составлен листок прибытия. Даже если события получения РВП и гражданства (и повторной регистрации) имели место в разные (смежные) календарные годы, повторный счет все равно завышал число прибывших.

По сути, в данном случае снова проявили себя проблемы методологии. В рамках описанных выше обстоятельств не было возможности обеспечить логику учета, согласно которой не должно быть ни недоучета мигрантов, ни их повторного счета, не говоря уже о необходимости корректного отражения характеристик мигрантов.

\section{ОСНОВНЫЕ ПРИЧИНЫ ПЕРЕХОДА В 2011 Г. НА НОВУЮ МЕТОДОЛОГИЮ И ЕЁ ПРИНЦИПЫ}

В условиях существования двух типов регистрации (по месту пребывания и месту жительства) в отношении граждан России и большой части потока иностранцев, оставалась нерешенной проблема значительного недоучета лиц, зарегистрированных по месту пребывания на длительные сроки. В их число входили, в частности, иногородние и иностранные студенты, приезжающие на несколько лет к месту обучения, фактически входя в состав населения города и региона, где располагалось учебное заведение. Было принято решение, начиная с 2011 г. обязать подразделения ФМС России составлять листки статистического учета не только на мигрантов, зарегистрированных по месту жительства, но также в отношении тех лиц, которые были зарегистрированы по месту пребывания на 9 месяцев и более. Российские статистики, переходя на новую методологию учета, исходили из особенностей нашего законодательства. Граждане РФ ${ }^{8}$ имеют право 90 дней после прибытия не регистрироваться по месту пребывания или месту нового жительства, по истечении трех месяцев они обязаны получить регистрацию по месту жительства или по месту пребывания. Если срок такой регистрации превышает 9 месяцев, то в сумме с первыми тремя месяцами период составит год и более, что соответствует критериям $\mathrm{OOH}$, рекомендуемым для учета долгосрочной миграции. Первичная регистрация для большинства иностранцев, прибывающих в РФ на срок свыше 72 часов, оформляется, как правило, на 90 дней. Её продление на более длительный срок возможно, например, при наличии контракта на работу, документов, подтверждающих учебу в вузе или колледже и др.

Если в отношении прибывших, на первый взгляд, все было относительно понятно, то учет выбытий лиц, зарегистрированных по месту пребывания, создавал значительные проблемы. Они были связаны с технологией сбора данных - на бумажных носителях и

и $26 \%$ соответственно). Отметим, что по международным соглашениям процедура приема в гражданство занимала три месяца после подачи заявления и без условия получения РВП или вида на жительство.

${ }^{8}$ И граждане Украины, прибывшие с частной или туристической целью. 
однократно в момент регистрации выбытия. Другой причиной (с которой непосредственно связана первая) являлось отсутствие у миграционных органов базы данных, позволяющей оперативно информировать органы статистики о выезде «временных» мигрантов к новому месту пребывания в пределах России или их выбытии за рубеж. (Эти трудности остаются непреодоленными и сейчас.) Поэтому было принято решение, что моментом выбытия следует считать дату окончания временной регистрации. Эта дата указывается в листке или форме учета прибывших (с 2019 г.) и вводится в базу данных Росстата при переносе информации с бумажных носителей. Иными словами, когда наступает дата окончания временной регистрации, мигранты автоматически считаются выбывшими. Международные мигранты «отправляются» в страну прежнего проживания, а внутрироссийские - в регион, где они зарегистрированы по месту жительства. В отношении лиц, имевших регистрацию по месту жительства, процедура учета оставалась прежней.

В потоках внутрироссийской миграции выбытия фиксировались на основе сведений о предыдущем месте жительства прибывших, т. е. прибывшие в регион одновременно учитывались как выбывшие в регионе предыдущего жительства. Для лиц, снимающихся с регистрационного учета в связи с выездом на постоянное место жительства (ПМЖ) за рубеж, составлялись листки выбытия. По мнению специалистов Росстата, переход к новой методологии позволил решить сразу две задачи: обеспечить более полный охват долгосрочных мигрантов вне зависимости от типа регистрации, в том числе студентов, и привести российскую методологию учета миграции в соответствие Рекомендациям ООН 1998 г. (United Nations 1998) ${ }^{9}$. Однако, как будет показано ниже, основная цель любой статистики - адекватное отражение действительности - оставалась труднодостижимой.

\section{ВЛИЯНИЕ НОВОЙ МЕТОДОЛОГИИ НА НЕКОТОРЫЕ ХАРАКТЕРИСТИКИ МИГРАЦИОННЫХ ПОТОКОВ}

Мы хотим начать с описания распределения мигрантов по типу и срокам регистрации, потому что именно эти новые переменные показывают масштабы изменений, которые привнесла с собой новая методология учета. Расчеты показали, что доля мигрантов с «временной» регистрацией чрезвычайно велика. Среди прибывших в Россию международных мигрантов, в среднем за 2012-2018 гг., она составила почти 73\%, а среди выбывших - 93\% (рисунки 1 и 2).

Таким образом, в потоках международной миграции с большим отрывом преобладают временные мигранты. В их число попадают и трудовые мигранты, имеющие основания для регистрации на срок свыше 9 месяцев. Многие из них лишь формально могут быть отнесены к постоянному населению. Распределение мигрантов, прибывших из отдельных стран мира, показывает, что доля временно зарегистрированных колеблется от примерно 50\% (США, Франция, Германия, Израиль) до 90\% и выше (Вьетнам, КНР, КНДР). Мигранты из стран СНГ имеют временную регистрацию в $65-85 \%$ случаев.

\footnotetext{
${ }^{9}$ Подробнее об этом см. (Чудиновских 2019: 61-76). 


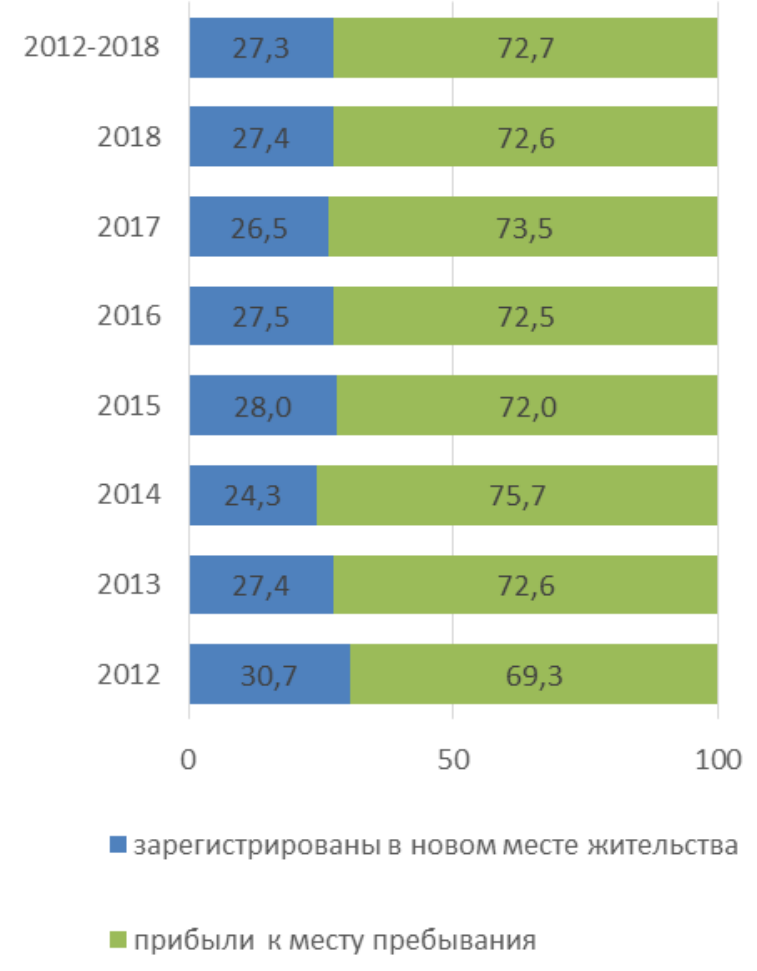

Рисунок 1. Распределение международных мигрантов, прибывших в Россию, по типу регистрации, 2012-2018, \%

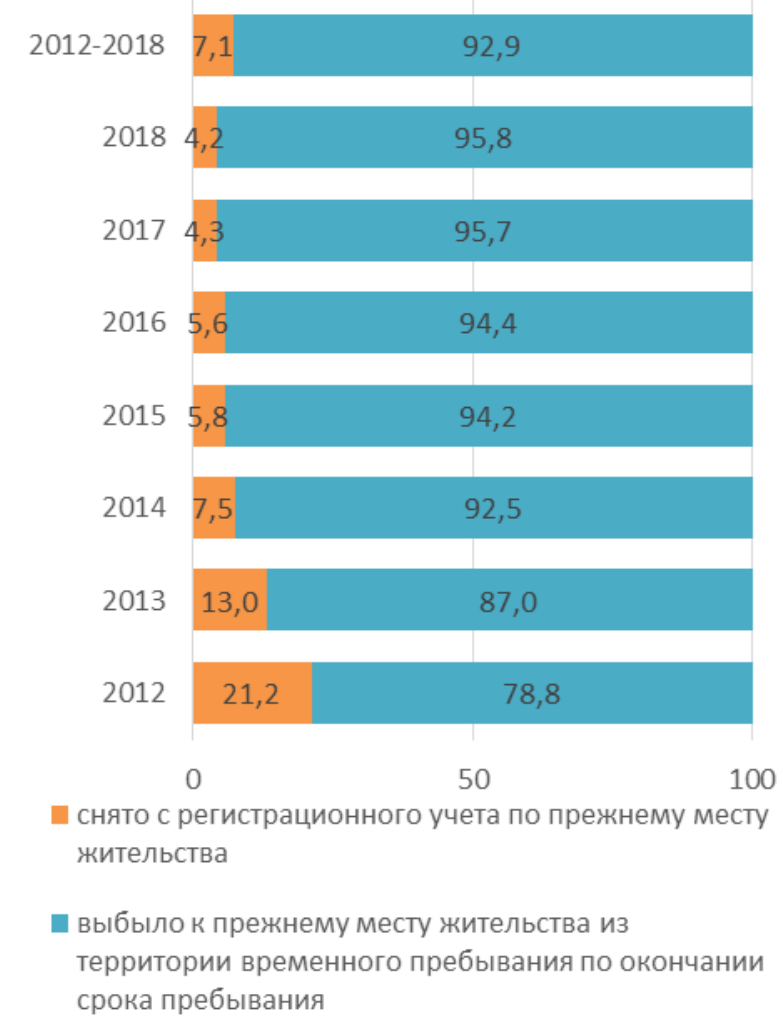

Рисунок 2. Распределение международных мигрантов, выбывших из России, по типу регистрации, 2012-2018, \%

Источник: Рассчитано авторами по (Росстат 2013...2019).

Потоки внутрироссийских мигрантов также лишь наполовину состоят из тех, кто является долгосрочным мигрантом в прежнем (до реформы 2011 г.) понимании, т. е. зарегистрировался по месту жительства. Остальная часть потока - это лица, оформившие регистрацию по месту пребывания на 9 месяцев и более. В отношении внутренней миграции новая методология внесла еще один элемент, который чрезвычайно затрудняет анализ и интерпретацию данных. Выбытия лиц с временной регистрацией в пределах России также учитываются на основании истекшего срока, и такие мигранты как бы «возвращаются» в регионы, где они зарегистрированы по месту жительства. Это происходит, даже если человек в месте постоянной прописки давно не живет. Такие «мигранты» выделяются в подгруппу возвратившихся после временного пребывания на другой территории. Ее доля значительна и в среднем за 2012-2018 гг. составила 20\% всех внутрироссийских переездов (рисунок 3). Заметим, что средняя по России не показывает масштаб проблемы по регионам. Например, в г. Москве в 2011-2018 гг. мигранты, «возвратившиеся после временного пребывания на другой территории», составили почти половину потока. Безусловно, анализ такой статистики весьма затруднителен, что уже отмечалось нами в работах прошлых лет (Чудиновских 2016: 3246). 


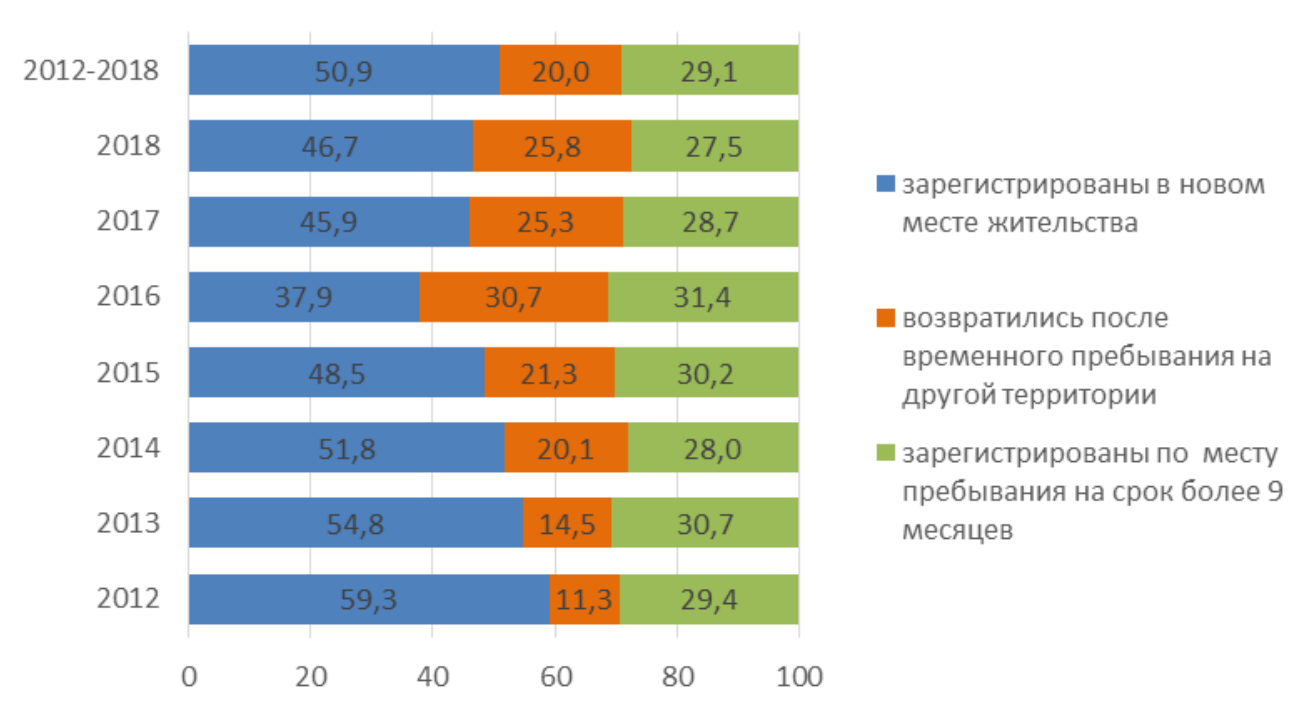

Рисунок 3. Распределение мигрантов, сменивших место жительства в пределах России в 2012-2018 гг., по типу регистрации, \%

Источник: Рассчитано авторами по (Росстат 2013...2019).

\section{ИЗМЕНЕНИЕ ОБЪЕМОВ МИГРАЦИИ}

Первый год применения новых правил (2011) показал резкий рост учтенных прибытий. Рост выбытий начался год спустя, когда в массовом порядке начал истекать срок временной регистрации мигрантов, прибывших в предыдущий год (таблица 1). По величине показатели международной миграции как по прибывшим, так и по выбывшим, стали соизмеримы с показателями первой половины 1990-х, когда на миграцию действовали иные факторы и ситуация была в целом совсем другой.

За период с 2011 по 2018 г. объем чистой миграции по России в целом составил 2025 тыс. человек, из которых только 999,2 тыс. были учтены как бы по старым правилам (за счет перемены места жительства), а 1025 тыс. - по новым (за счет регистрации по месту пребывания и истечения её срока; таблица 2).

Таблица 2. Чистая миграция в России за 2011-2018 гг. по типу регистрации, тыс.

\begin{tabular}{l|c|c|c}
\hline Год & $\begin{array}{c}\text { Всего } \\
\text { чистая миграция }\end{array}$ & $\begin{array}{c}\text { За счет регистрации по месту } \\
\text { жительства }\end{array}$ & $\begin{array}{c}\text { За счет регистрации по месту } \\
\text { пребывания }\end{array}$ \\
\hline 2011 & 319,8 & 106,7 & 213,0 \\
2012 & 294,9 & 102,0 & 192,9 \\
2013 & 295,9 & 108,0 & 187,8 \\
2014 & 270,0 & 117,1 & 153,0 \\
2015 & 245,4 & 147,4 & 98,0 \\
2016 & 261,9 & 140,4 & 121,5 \\
2017 & 211,9 & 139,7 & 72,2 \\
2018 & 124,9 & 137,9 & $-13,1$ \\
$2011-2018$ & 2024,7 & 999,2 & 1025,5 \\
\hline
\end{tabular}

Источник: Рассчитано авторами по (Росстат 2012...2019). 
Таким образом, если бы методология не менялась, чистая миграция за период с 2011 по 2018 г. была бы на миллион человек меньше. Мы не рассматриваем в рамках этой статьи региональные аспекты, но можно сказать, что на уровне регионов картина крайне неоднородная, имеют место большие колебания в компонентах миграционного прироста или убыли даже по смежным годам. Поскольку в статистику теперь попадает и значительное число трудовых мигрантов со статусом «временно пребывающих», но имеющих возможность зарегистрироваться на срок 9 месяцев и более, показатели текущего учета могут зависеть от краткосрочных колебаний спроса на иностранную рабочую силу, усложнения миграционного законодательства в отношении отдельных категорий мигрантов и др. Например, изменение правил допуска иностранцев к российскому рынку труда в 2015 г. и резкий рост затрат со стороны мигранта на легальную работу и нахождение в России могли привести к тому, что часть трудовых мигрантов перестали обращаться за патентами и предпочли приезжать и регистрироваться на короткие сроки. Подобные обстоятельства следует принимать во внимание при анализе статистики.

\section{СРОКИ РЕГИСТРАЦИИ ВРЕМЕННЫХ МИГРАНТОВ}

Распределение мигрантов по срокам временной регистрации показывает, что около 30\% потока международных мигрантов были зарегистрированы на срок до одного года (таблица 3). За короткий период наблюдения имели место колебания в диапазоне от 19\% до $39 \%$. Это косвенно подтверждает, что в число учтенных Росстатом долгосрочных мигрантов попадают и временные трудовые мигранты, которые являются таковыми и по статусу «временно пребывающих» ${ }^{10}$, и по срокам пребывания в России. С большой осторожностью можно сделать предположение, что не менее трети учтенного потока прибывших - это именно временные трудовые мигранты. Также в пользу этого говорит, как будет показано ниже, рост доли мигрантов, указавших, что прибыли с целью работы.

Мы полагаем, что большая часть мигрантов, которые регистрируются на условно небольшие сроки (от 9 месяцев до года), находятся в России, не превышая критерий 12-месячного пребывания, который делает мигранта долгосрочным. Мы предположили также, что даже в следующем интервале от $>1$ до $<2$ лет реальные сроки регистрации смещены в сторону 12, а не 24 месяцев. В нашем распоряжении была полученная с разрешения Росстата неагрегированная информация о миграции в г. Москву за 2017 г. Разработка данных о детализированных сроках регистрации показала, что встречаются записи, в которых срок пребывания составляет даже 8 месяцев. Кроме того, подтвердилось наше предположение, что частота регистраций в интервале свыше года и до двух лет была смещена в сторону 12 месяцев (рисунок 4). Это в еще большей мере вызывает сомнения в абсолютной правомочности отнесения части этих мигрантов к долгосрочным.

\footnotetext{
${ }^{10}$ Определения статуса иностранных граждан в Российском законодательстве (впрочем, как и в других странах) отличаются от определений мигранта, принятых в статистике. Статус временно пребывающего распространяется на всех лиц, за исключением тех, кто имеет РВП и вид на жительство. Долгосрочная виза, действительный патент дают право иностранцу находится на территории России годами, но это не меняет их статуса временно пребывающих. Но основная часть лиц без РВП и видов на жительство все-таки не может быть отнесена к постоянному населению.
} 
Доля иностранцев, зарегистрированных по месту пребывания на срок не более 12 месяцев в Москве, составила $27 \%$ от всех временно зарегистрированных.

Таблица 3. Международная миграция. Распределение прибывших к месту пребывания на 9 месяцев и более по срокам регистрации, 2012-2018 ${ }^{11}$, \%

\begin{tabular}{l|c|c|c|c|c|c}
\hline Год & $\begin{array}{c}\text { От 9 месяцев } \\
\text { до 1 года }\end{array}$ & 1 год & 2 года & 3 года & 4 года & 5 лет и более \\
\hline 2012 & 33,5 & 19,3 & 29,5 & 7,6 & 7,4 & 2,7 \\
2013 & 38,8 & 19,3 & 26,0 & 6,5 & 6,8 & 2,5 \\
2014 & 37,1 & 17,9 & 28,2 & 6,8 & 7,4 & 2,7 \\
2015 & 20,7 & 21,3 & 36,3 & 8,6 & 9,6 & 3,4 \\
2016 & 19,1 & 24,4 & 31,2 & 8,9 & 12,1 & 4,3 \\
2017 & 22,7 & 26,2 & 25,9 & 8,7 & 12,2 & 4,4 \\
2018 & 22,7 & 27,4 & 23,9 & 8,6 & 12,5 & 4,9 \\
$2012-2018$ & 27,3 & 22,4 & 28,8 & 8,0 & 9,9 & 3,6 \\
\hline
\end{tabular}

Источник: Рассчитано авторами по (Росстат 2013...2019).

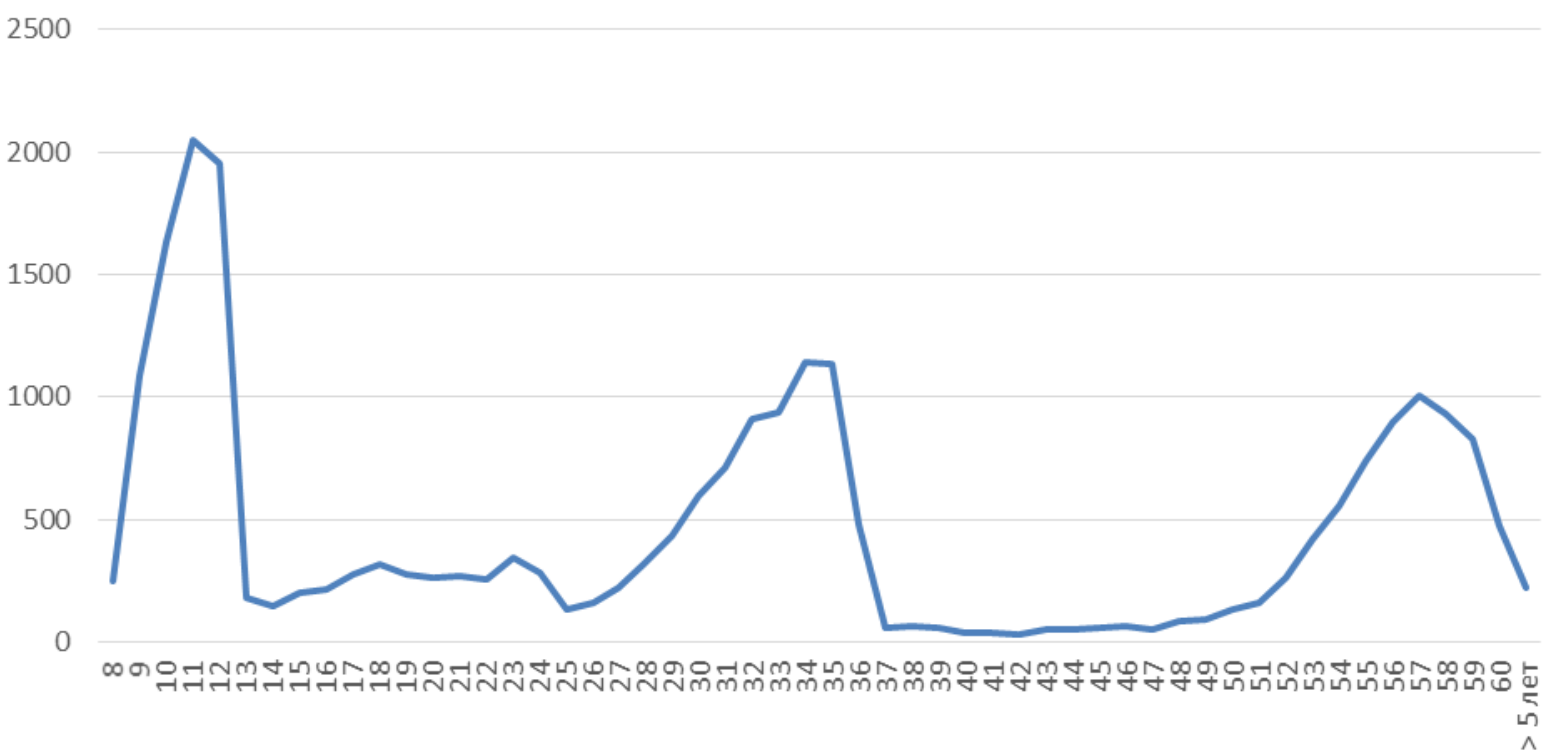

Рисунок 4. Распределение мигрантов - иностранных граждан, прибывших в г. Москву в 2017 г., по срокам регистрации (числу месяцев), человек

Источник: Данные Росстата.

Иными словами, формально долгосрочные мигранты из этой подгруппы также демонстрируют своего рода «текучесть». Отчасти это связано с правилами регистрационного учета: требуется основание для регистрации мигранта на срок свыше 9 месяцев, а также помещение, собственник которого согласится зарегистрировать этого человека. Причем это может быть не только физическое лицо, но и организация, которая выступает принимающей стороной для этого иностранца ${ }^{12}$.

\footnotetext{
11 По отдельным характеристикам миграционных потоков мы рассматриваем период, начиная не с 2011 г., а с 2012, поскольку в 2011 г. еще не проявили себя итоги применения новой методологии при учете выбытий. $12 \mathrm{~B}$ законе «О миграционном учете иностранных граждан и лиц без гражданства в Российской Федерации» (от 18 июля 2006 г. №109-Ф3) сказано, что «иностранный гражданин подлежит постановке на учет по месту
} 

Таблица 4. Внутрироссийская миграция. Распределение прибывших к месту
пребывания на 9 месяцев и более по срокам регистрации, 2012-2018, \%

\begin{tabular}{l|c|c|c|c|c|c}
\hline Год & $\begin{array}{c}\text { От 9 месяцев } \\
\text { до 1 года }\end{array}$ & 1 год & 2 года & 3 года & 4 года & 5 лет и более \\
\hline 2012 & 16,8 & 31,3 & 14,5 & 18,2 & 6,8 & 12,3 \\
2013 & 17,2 & 31,1 & 13,9 & 17,3 & 7,1 & 13,5 \\
2014 & 15,8 & 30,9 & 13,3 & 17,2 & 7,2 & 15,5 \\
2015 & 15,4 & 29,2 & 12,9 & 17,5 & 7,5 & 17,5 \\
2016 & 14,3 & 29,7 & 13,2 & 17,3 & 7,2 & 18,3 \\
2017 & 14,9 & 28,6 & 13,1 & 17,0 & 7,5 & 18,8 \\
2018 & 14,8 & 28,5 & 12,6 & 16,4 & 7,6 & 20,1 \\
$2012-2018$ & 15,6 & 29,9 & 13,4 & 17,3 & 7,3 & 16,6 \\
\hline
\end{tabular}

Источник: Рассчитано авторами по (Росстат 2013...2019).

Распределения внутрироссийских и международных временных мигрантов по срокам регистрации существенно отличались (таблицы 3 и 4). Во-первых, среди внутренних мигрантов процент лиц с короткими сроками регистрации был почти вдвое меньше, а вовторых, за период наблюдения доли групп с разными сроками регистрации оставались практически неизменными.

Мы полагаем, что в перспективе, когда (и если) появится больше определенности в отношении учета досрочных выбытий, повторных приездов и других обстоятельств, влияющих на качество статистики (об этом речь пойдет ниже), информация о сроках регистрации будет иметь больший аналитический смысл. В сочетании с некоторыми макроэкономическими показателями или сведениями об изменении миграционной политики, сведения о динамике сроков регистрации частично могут отражать сдвиги в миграционном поведении в первую очередь международных мигрантов. Но в данном случае больше надежд мы связываем с административными данными и IT-ресурсами Главного управления по вопросам миграции МВД России, «статистический потенциал» которых в значительной степени не был реализован. К сожалению, это вопрос неопределенного будущего, поскольку в последнее время обнажились большие проблемы, связанные с полнотой и качеством этих данных ${ }^{13}$.

Наиболее очевидно проявились результаты введения новой методологии учета в отношении таких переменных, как направления (откуда прибыли и куда выбыли), гражданство и причины переезда.

пребывания по адресу организации, в которой он в установленном порядке осуществляет трудовую или иную не запрещенную законодательством Российской Федерации деятельность, в случае фактического проживания по адресу указанной организации либо в помещении указанной организации, не имеющем адресных данных (строении, сооружении), в том числе временном».

13 Счетная палата нашла ошибки в системах миграционного учета (2020). РИА Новости, 3 марта. URL: https://ria.ru/20200303/1567454068.html. В статье, в частности, говорится, что при проверке было выявлено «большое количество недостоверных данных в государственных информационных системах паспортновизовых документов и миграционного учета». 


\section{ИЗМЕНЕНИЕ СТРУКТУРЫ МЕЖДУНАРОДНОЙ МИГРАЦИИ ПО СТРАНАМ ИСХОДА И НАЗНАЧЕНИЯ}

На рисунках 5 и 6 видно, что в 2011 г. существенно изменился состав потоков по странам исхода и (с лагом в один год) странам назначения мигрантов. Заметно выросли доли мигрантов, прибывших из главной страны-донора трудовой миграции - Узбекистана (с 13\% в 2010 г. до 18\% в 2011 г. и 25\% в 2013 г.). С 2014 г. начался рост доли прибывших с Украины, многие из которых сохраняли временный статус и не обращались за предоставлением убежища.

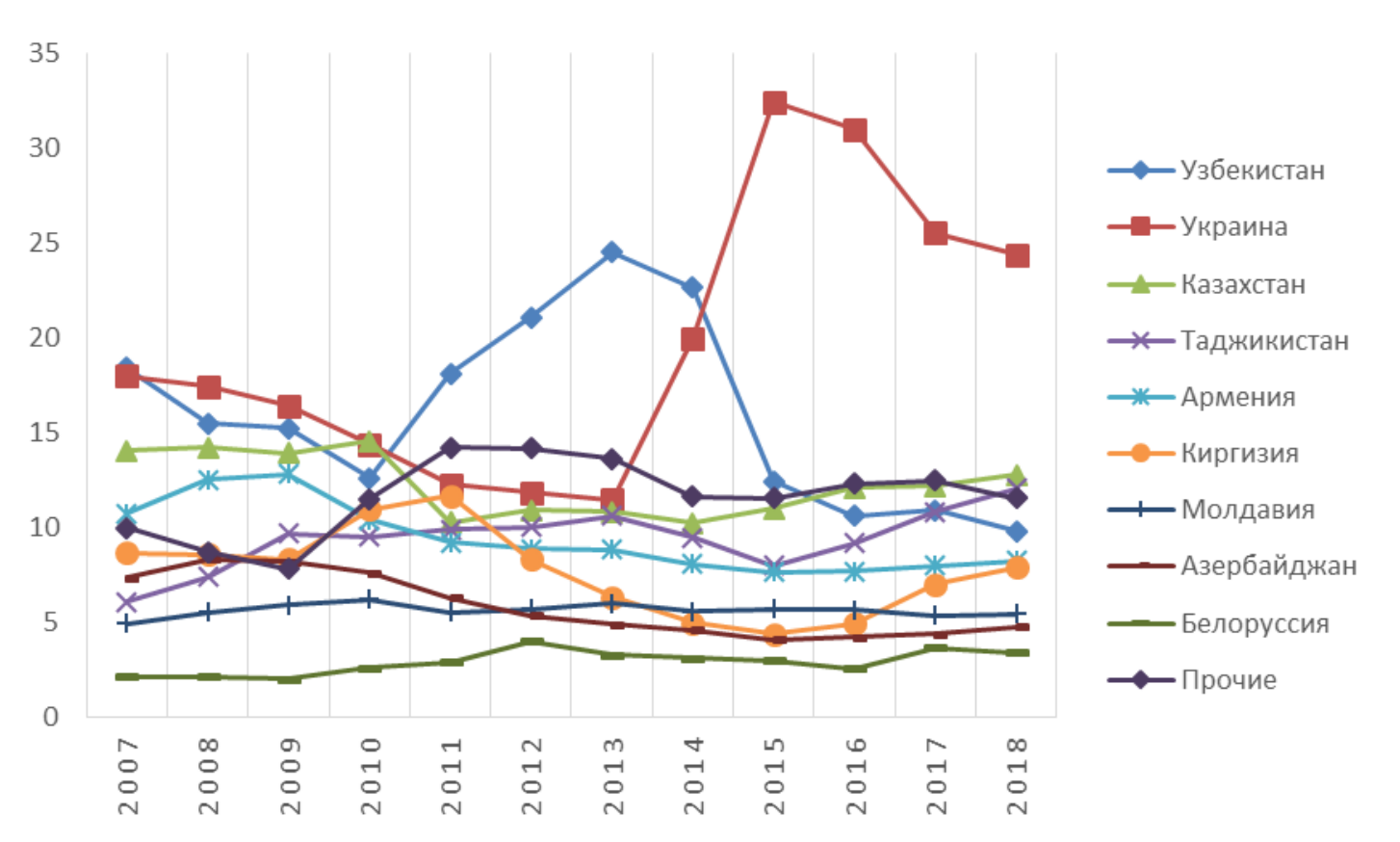

Рисунок 5. Доля мигрантов, прибывших в России из отдельных стран мира, в общем потоке, 2007 -2018, \%

Источник: Рассчитано авторами по (Росстат 2008...2019).

Вслед за потоками прибывших изменилась и структура выбывших (рисунок 6), и динамика была еще более значительной. Неудивительно, что с 2012 г. главной особенностью стал рост доли выбывших в Узбекистан, ставший основной страной назначения мигрантов из России. В 2014 г. они составили почти треть потока. Затем можно увидеть увеличение доли выбывших на Украину по истечении срока временной регистрации. Вполне вероятно, что жители этой страны никуда не выезжали, а переоформляли временную регистрацию. В первые годы украинского кризиса в отношении этих мигрантов были упрощены правила миграционного учета, и люди могли довольно долго находиться в России, переоформляя регистрацию. 


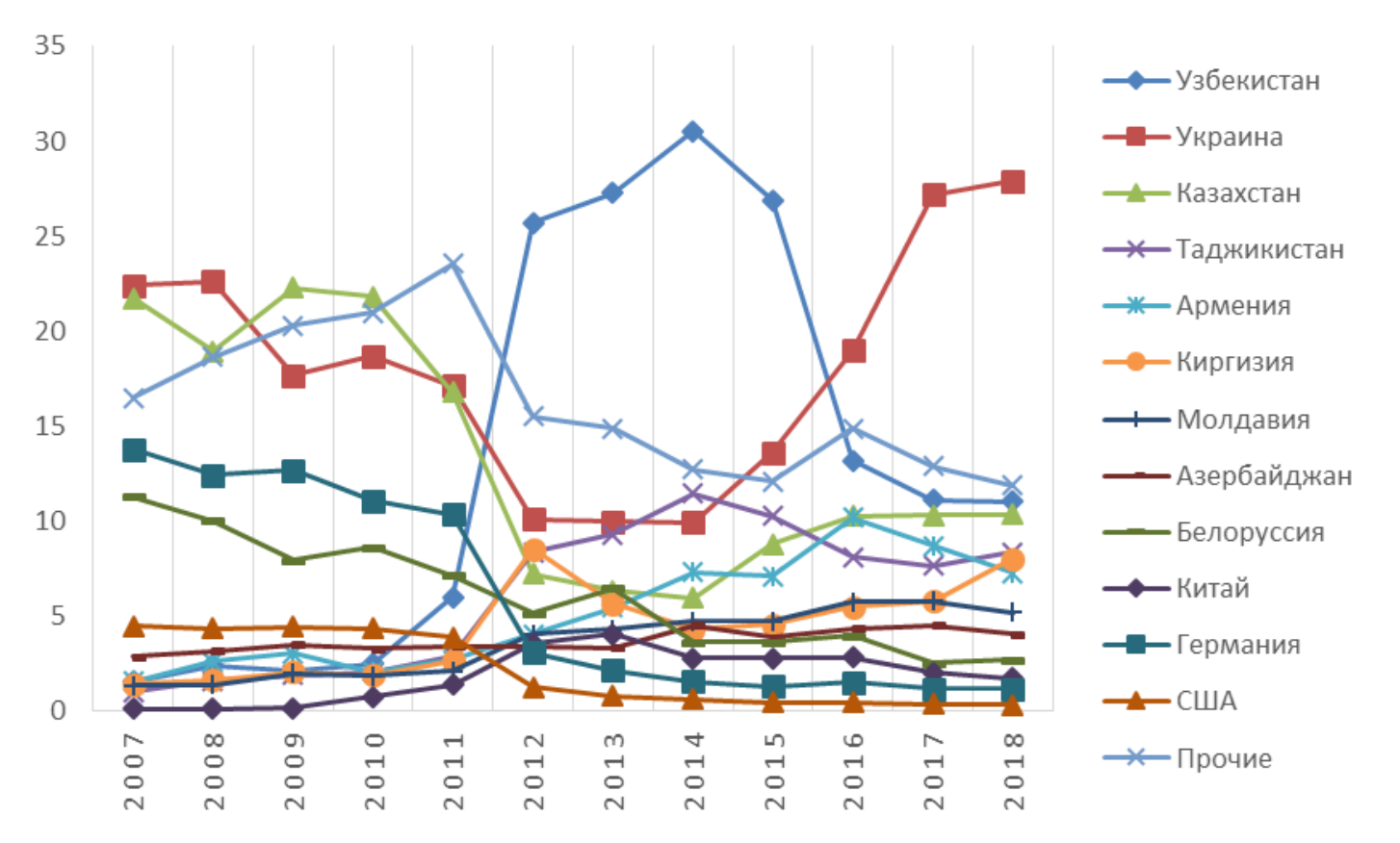

Рисунок 6. Доля мигрантов, выбывших из России в отдельные страны мира, в общем потоке, 2007 -2018, \%

Источник: Рассчитано авторами по (Росстат 2008...2019).

\section{СОСТАВ МИГРАНТОВ ПО ГРАЖДАНСТВУ}

Новая методология привела к мгновенному и кардинальному изменению соотношения граждан России и иностранцев в потоках прибывших и, естественно, выбывших, поскольку в большинстве своем по характеристикам это одни и те же лица.

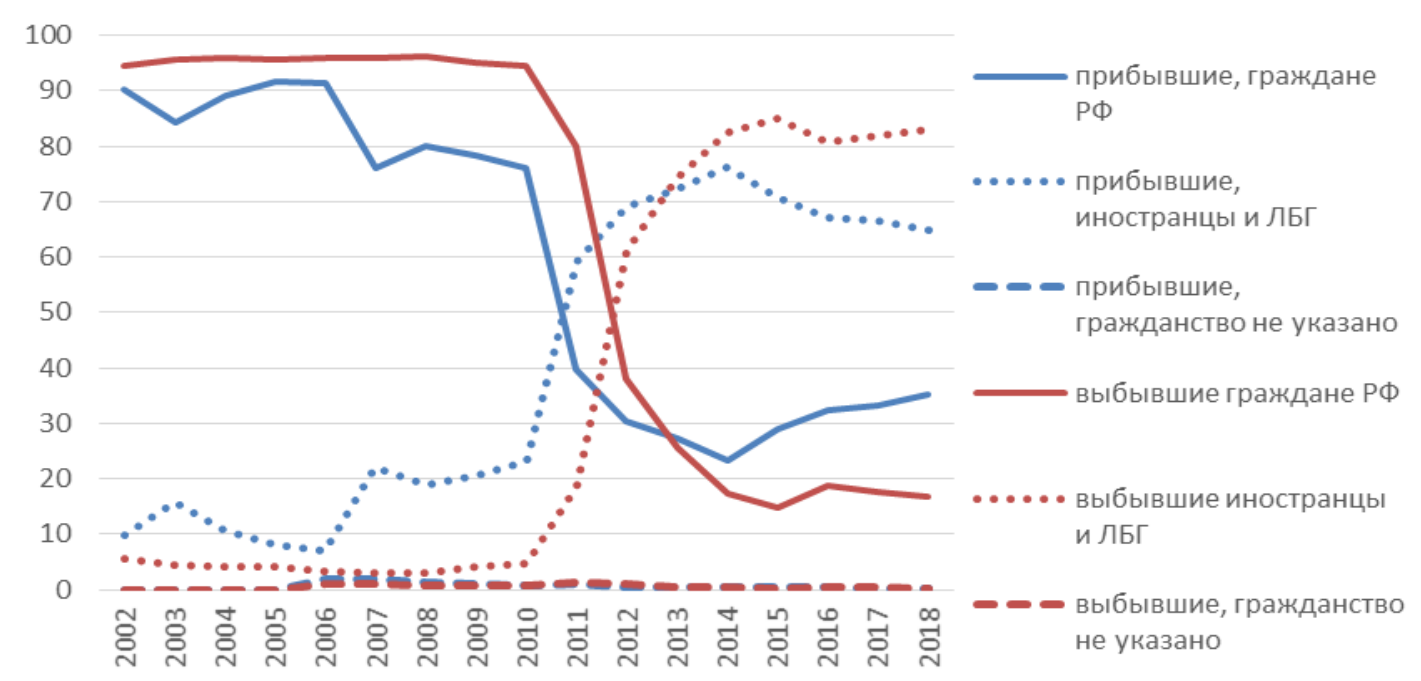

Рисунок 7. Доля граждан Российской Федерации и иностранцев (включая лиц без гражданства) в потоках международной миграции, 2002-2018, \%

Источник: Рассчитано авторами по (Росстат 2003...2019).

Примечание: ЛБГ-лица без гражданства. 
Рисунок 7 демонстрирует стремительный рост доли иностранцев среди прибывших с $23 \%$ в 2010 г. до $60 \%$ в 2011 г. и $76 \%$ в 2014 г. (это был год максимального за всю постсоветскую историю притока трудовых мигрантов, среди которых также было много лиц с долгосрочной регистрацией). Если подойти к таким изменениям формально, то высокая доля иностранцев в потоке прибывших - нормальное явление. Но абсолютное преобладание иностранцев среди эмигрантов вызывает вопросы. Конечно, в потоках эмиграции вполне могут присутствовать и неграждане страны выбытия, но их не должно быть большинство. В противоположном случае, а точнее - в нашем, мы имеем дело со статистикой, которая в большинстве случаев отражает виртуальную, а не реальную эмиграцию. Частично такое распределение мигрантов по гражданству может свидетельствовать о преобладании циркулярной миграции ${ }^{14}$, когда иностранцы прибывают без намерения поселиться в новой стране, с определенной периодичностью возвращаются на родину, чтобы потом снова поехать на заработки за рубеж. Однако проверить это предположение невозможно в силу архаичной технологии сбора первичных данных. В этой связи возникает вопрос, насколько правомочно включать циркулярных мигрантов в постоянное население.

\section{ПРИЧИНЫ ПЕРЕЕЗДА}

Переход на новую методологию привел к существенным сдвигам в структуре причин переезда. Как и предполагалось, включение в статистику временных трудовых мигрантов резко увеличило долю прибывших с целью работы. Причем колебания числа прибывших и их удельного веса в потоке в период с 2011 до 2018 г. совпадали с картиной колебаний притока трудовых мигрантов, получивших патент или разрешение на работу ${ }^{15}$. Также увеличилось число лиц, указавших целью переезда учебу (таблица 5).

Не ставя перед собой цели анализировать колебания состава потока по причинам переезда, отметим, что заявленная при переходе на новую методологию цель улучшения учета студентов, по крайней мере, в отношении международной миграции, была достигнута лишь частично.

\footnotetext{
${ }^{14}$ Циркулярная миграция подразумевает повторяющийся миграционный опыт человека между странами происхождения и назначения, фактически термин относится к людям, которые делят работу, семейную жизнь или иные стороны своей жизни между двумя или более месторасположениями (Hugo 2013). Это явление получило большую распространенность в мире, но единого определения не существует, так как возможны вариации миграционного поведения циркулярных мигрантов (подробнее United Nations 2016: 34).

15 Регистрация по месту пребывания на длительный срок лиц лиц, не имеющих документов на право работы или учебы, маловероятна. Поэтому в статистику Росстата попадают с большей вероятностью все-таки законные трудовые мигранты. Показатели ГУВМ МВД России о числе лиц, поставленных на миграционный учет (с разной длительностью) с целью работы достигают 5 млн человек ежегодно (см.

https:/мвд.pф/Deljatelnost/statistics/migracionnaya, отчет «Отдельные показатели миграционной ситуации в Российской Федерации с распределением по странам и регионам»). Но лишь небольшая часть из них имеет шанс быть учтенными в качестве долгосрочных мигрантов. Как было отмечено специалистами ГУВМ МВД России в ходе консультации с ними авторов статьи, даже граждане стран ЕАЭС преимущественно находятся в России ограниченное время, оставаясь в большей степени краткосрочными или циркулярными мигрантами.
} 
Таблица 5. Число мигрантов в возрасте 14 лет и старше, прибывших с целью работы и учебы, и их доля в общем потоке прибывших в Россию, 2001-2018

\begin{tabular}{l|c|c|c|c}
\hline \multirow{2}{*}{ Год } & \multicolumn{2}{|c|}{ Прибыли с целью работы } & \multicolumn{2}{c}{ Прибыли с целью учебы } \\
\cline { 2 - 5 } & тыс. человек & $\begin{array}{c}\text { доля в общем потоке, } \\
\%\end{array}$ & тыс. человек & $\begin{array}{c}\text { доля в общем потоке, } \\
\%\end{array}$ \\
\hline 2001 & & 8,1 & 5,9 & 3,7 \\
2002 & 13,1 & 6,8 & 5,6 & 3,5 \\
2003 & 10,7 & 5,9 & 3,0 & 2,7 \\
2004 & 6,6 & 5,2 & 2,7 & 2,8 \\
2005 & 5,4 & 4,7 & 4,3 & 2,3 \\
2006 & 7,3 & 7,5 & 3,7 & 1,2 \\
2007 & 12,2 & 9,1 & 3,2 & 1,4 \\
2008 & 23,4 & 9,4 & 3,5 & 2,5 \\
2009 & 24,2 & 11,2 & 4,0 & 3,6 \\
2010 & 29,1 & 13,9 & 4,5 & 4,5 \\
2011 & 24,4 & 27,2 & 12,1 & 4,9 \\
2012 & 90,6 & 33,3 & 17,4 & 6,9 \\
2013 & 130,1 & 37,6 & 22,0 & 7,3 \\
2014 & 170,1 & 34,7 & 26,6 & 7,3 \\
2015 & 187,5 & 20,1 & 33,8 & 7,8 \\
2016 & 108,6 & 18,0 & 36,8 & \\
2017 & 93,1 & 22,7 & 39,0 & \\
2018 & 121,2 & 22,1 & 39,9 & \\
\hline
\end{tabular}

Источник: Рассчитано авторами по (Росстат 2002...2019).

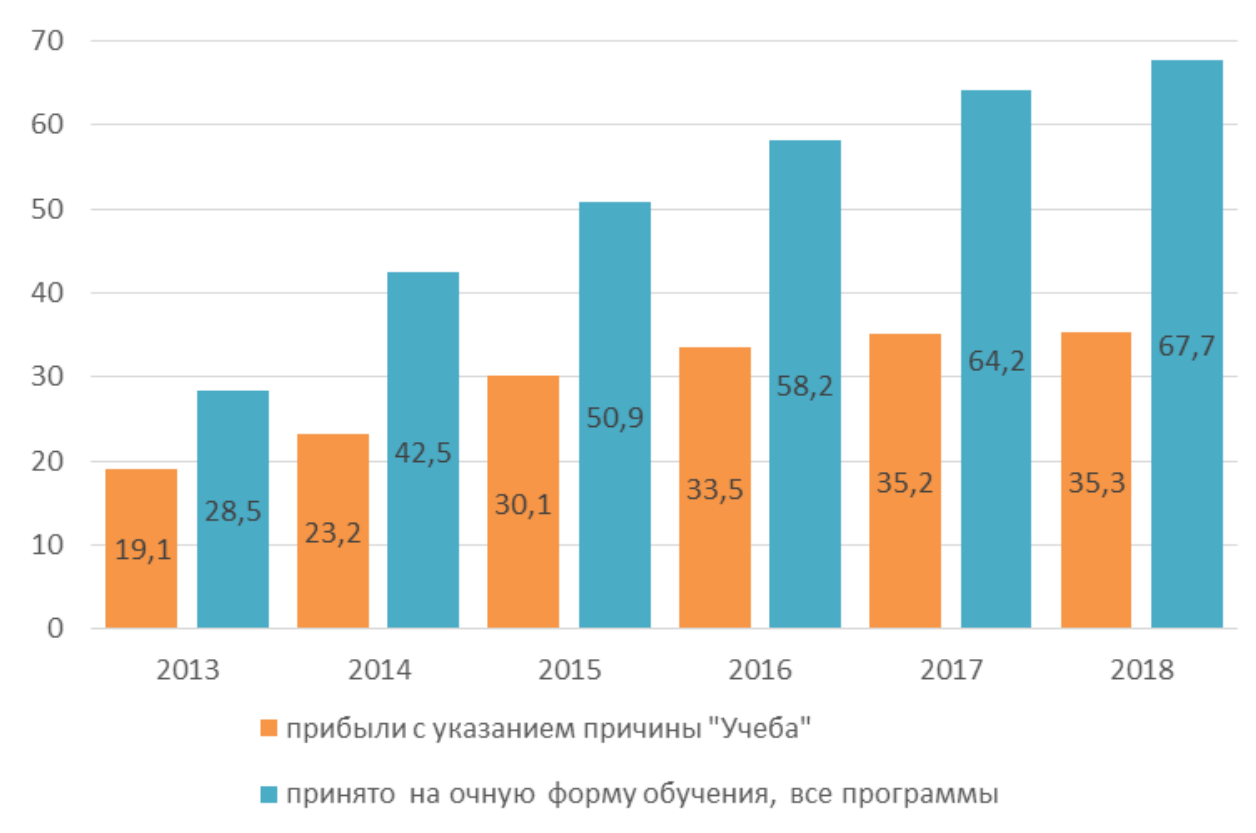

Рисунок 8. Число иностранных граждан в возрасте 14 лет и старше, прибывших на учебу, и число иностранных студентов, принятых на очную форму обучения в вузы России, 2013-2018, тыс.

Источник: Рассчитано авторами по (Росстат 2013...2019) и данным Министерства высшего образования и науки России 16

${ }^{16}$ URL: https://minobrnauki.gov.ru/ru/activity/stat/highed/index.php 
По данным Министерства высшего образования и науки ${ }^{17}$, в 2013-2018 гг. на очную форму обучения в вузы России всего были приняты около 312 тыс. иностранных граждан. В те же годы суммарный поток прибывших иностранцев с указанием цели переезда «учеба» (без учета типа учебного заведения) составил 176 тыс. человек (рисунок 8). Таким образом, недоучет иностранных студентов в этот период составил как минимум 43\% потока.

В наибольшей степени новая методология сказалась на точности учета характеристик выбывших. «Виртуальным» эмигрантам автоматически приписываются характеристики, указанные в записи о прибытии. Корректировке подвергаются только возраст и (начиная с 2016 г.) причины выбытий (это предусмотрено алгоритмом разработки данных в вычислительном центре Росстата). Остальные параметры (образование, семейное положение и прочее) просто копируются. Если в отношении лиц с самыми короткими сроками регистрации это условно может быть верным, то за 2-3 года пребывания в отношении других характеристик у человека может измениться многое.

Но самые большие трудности возникли при определении причин переезда лиц, которые автоматически считались выбывшими по истечении срока регистрации (рисунок 9). Безусловно, неверно было указывать для «выбывших» в связи с истекшим сроком регистрации ту же причину, по которой они прибыли. Стремясь исправить эту ошибку, начиная с 2016 г., Росстат в отношении мигрантов, «выбывших» в связи с окончанием срока регистрации, указывает причину «возвратились после временного отсутствия», которая сейчас, как видно на рисунке 9, распространяется на 96\% потока. Понятно, что аналитическая ценность такой информации очень невелика.

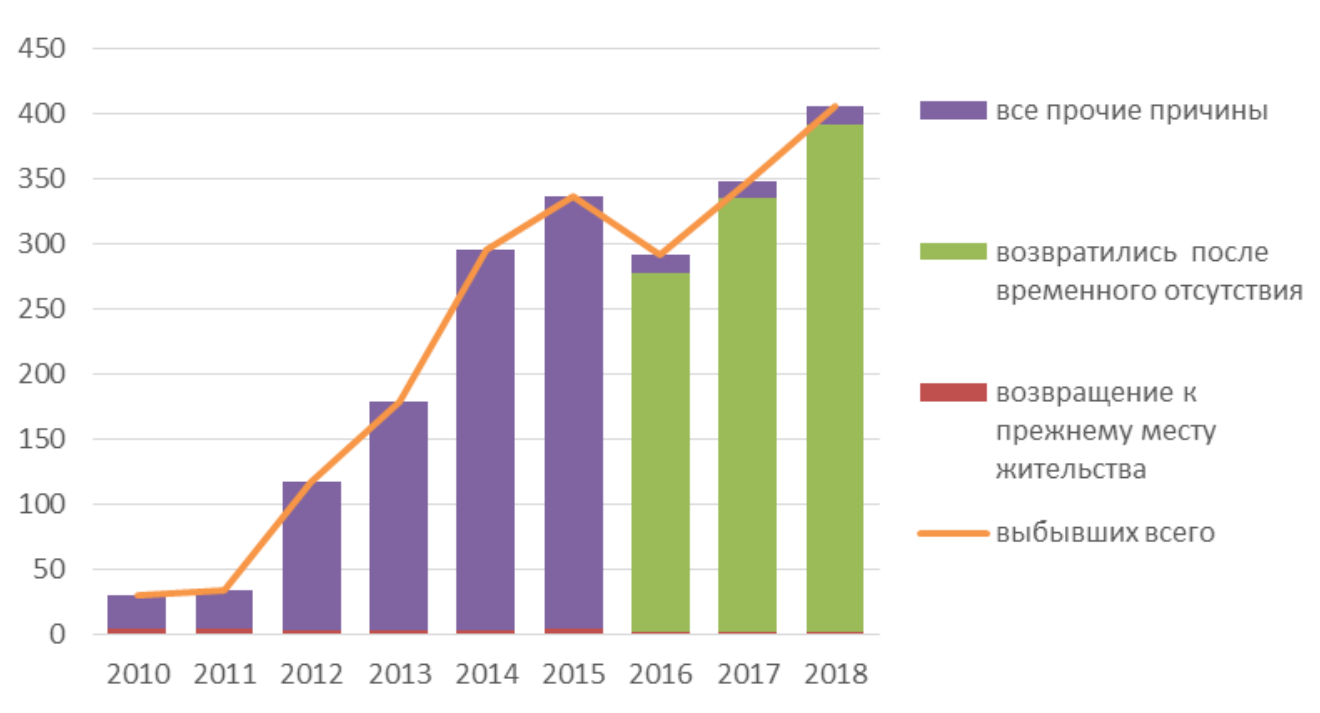

\section{Рисунок 9. Распределение международных мигрантов, выбывших из России, по основным причинам выбытия, 2010-2018, тыс.}

Источник: Рассчитано авторами по (Росстат 2011...2019).

${ }^{17}$ В настоящее время данные собираются в рамках федерального статистического наблюдения по форме ВПО-1. Аналогичная форма федерального статистического наблюдения СПО-1 ежегодно заполняется и в системе среднего профессионального образования. Число иностранных студентов в системе СПО, принятых в учебные заведения России, невелико. URL: https://edu.gov.ru/activity/statistics/secondary_prof_edu 


\section{ОСНОВНЫЕ УЯЗВИМОСТИ НОВОЙ МЕТОДОЛОГИИ ТЕКУЩЕГО УЧЕТА}

Несмотря на понятную цель - улучшить текущий учет миграции, на практике результаты применения новой методологии оказались неоднозначными. В настоящее время трудно сказать, был ли полученный эффект только положительным. В основу методологии негласно заложены весьма серьезные допущения и условия, которые на деле могут и не выполняться в отношении большой части мигрантов. Каковы эти допущения, и в чем мы видим их основные уязвимости с точки зрения качества статистики?

Первое допущение связано с тем, что постановка на миграционный учет иностранцев и регистрационный учет граждан РФ на срок 9 месяцев и более происходит только после 3 месяцев пребывания в «неопределенном» статусе. Но у нас нет доказательств, что абсолютно все делают именно так. Вероятно, многие сразу оформляют регистрацию на весь срок предполагаемого пребывания. Поэтому мигранты, зарегистрированные сразу на срок от 9 до $<12$ месяцев, не относятся к целевой группе проживающих свыше года, и в этом случае имеет место переучет долговременной миграции. Как было показано ранее, доля таких людей достаточно велика, в особенности среди международных мигрантов.

Второе допущение предполагает, что все мигранты, намеревающиеся находиться в месте прибытия свыше 9 месяцев, оформляют регистрацию сразу на весь предполагаемый срок пребывания. Но в законе нет такого требования. Если для граждан России, возможно, это и близко к истине, то для иностранцев весьма велика вероятность «дробной» постановки на миграционный учет, хотя бы потому, что на короткие сроки регистрацию оформить существенно проще. Есть основания полагать, что фактическое продление регистрации лицам, работающим по патенту, тоже оформляется каждый раз заново, когда человек оплачивает очередной период действия патента. Поэтому, если человек в течение года несколько раз регистрировался на короткие сроки, то, даже если в совокупности они превышают 9 месяцев, он или она не будут учтены Росстатом. Это ведет к недоучету мигрантов с длительным суммарным сроком пребывания, и число таких людей может быть значительным.

Третье допущение касается длительности пребывания мигранта в месте регистрации. Предполагается, что все мигранты остаются в месте временной регистрации до момента ее окончания и только потом выбывают. Но нет данных, подтверждающих эту гипотезу. Многие мигранты выезжают до окончания срока регистрации. Если для граждан РФ «временная» регистрация в случае выезда и возвращения не прерывается, то для иностранца она автоматически прерывается при пересечении границы. По возвращении нужно оформлять новую регистрацию. Это создает большую вероятность недоучета выбытий и повторного счета прибытий.

Четвертое допущение подразумевает, что мигранты (и внутрироссийские, и международные) не перемещаются между разными местами пребывания, а только между местом жительства и местом пребывания и обратно. При учете прибытий в качестве территории, откуда человек прибыл, указывается место постоянной регистрации или страна постоянного жительства (для прибывших из-за рубежа). Например, лица, имевшие временную регистрацию в регионе А и переехавшие в регион Б (также с оформлением 
временной регистрации), будут здесь учтены как прибывшие из региона $\mathrm{C}$, где человек зарегистрирован постоянно. И в регион С Росстат «отправит» этих людей по истечении срока регистрации. Если выбытие из места пребывания произошло до этого срока, и мигрант оформил новую регистрацию в другом месте пребывания, то здесь его учтут как прибывшего из места постоянной регистрации и произойдет повторный учет выбытий из региона, где человек зарегистрирован постоянно. Поскольку данные не персонифицированы, никакие корректировки не возможны.

Пятое допущение также имеет «географический» смысл и связано с предыдущим местом жительства. Предполагается, что все мигранты с истекшей временной регистрацией выбывают туда же, откуда прибыли. В отношении основной части международных мигрантов, видимо, это может быть верно, но в отношении внутрироссийских мигрантов это часто может не соответствовать действительности. Такое допущение ведет к погрешности в распределении потока выбывших по регионам, а также в расчете чистой миграции по направлениям.

Перечисленные проблемы добавляются к традиционному недекларированию выбытий и прибытий как в пределах России, так и в отношении международной миграции (в основном - выбытия граждан России). Метод «зеркальной статистики» для оценки масштабов недоучета эмиграции из России применим в отношении некоторых направлений миграции, например - стран дальнего зарубежья ${ }^{18}$. К тому же он не применим к внутренней миграции.

\section{ОБ ИНФОРМИРОВАНИИ ПОЛЬЗОВАТЕЛЕЙ}

Перечисленные проблемы не только показывают риски нашей статистики с позиций качества, но и затрудняют ее интерпретацию и анализ. В этих условиях частично пролить свет на проблемы и одновременно просветить значительную часть пользователей могли бы аналитические материалы, подготовленные специалистами Росстата. Не менее важную роль должна играть внятно изложенная методология. К сожалению, сейчас она представлена в таком лапидарном стиле, что даже специалистам непросто понять, в чем суть дела и как собиралась статистика в недавнем прошлом. В настоящее время на сайте Росстата сказано следующее: «До 2019 года листки статистического учета прибытия и листки статистического учета выбытия (Приложение №12 Административного регламента предоставления услуги по регистрационному учету граждан Российской Федерации по месту пребывания и по месту жительства в пределах Российской Федерации, формы №№12П и 12В). Начиная с января 2019 года, формы федерального статистического наблюдения: 1-ПРИБ, 1-ВЫБ, 1-ПРИБ_ИнГР,1-ВЫБ» ${ }^{19}$. Эти аббревиатуры мало что

\footnotetext{
${ }^{18}$ Оценки, выполненные М.Б. Денисенко с применением этого метода, продемонстрировали, что российские показатели эмиграции были многократно занижены по сравнению с данными об иммигрантах из России в ряде стран Запада. Например, в 2015 г. расхождения составили по Германии 23 раза, Испании 28 раз, Канаде 11 раз, Австрии 23 раза (Denisenko 2020: 83). Недоучет эмиграции из России является хронической проблемой, и подобные расхождения имели место и ранее (Денисенко 2012).

${ }^{19}$ URL: https://gks.ru/storage/mediabank/\%D0\%9C\%D0\%B8\%

D0\%B3\%D1\%80\%D0\%B0\%D1\%86\%D0\%B8\%D1\%8F(1).html
} 
говорят о методологии сбора и разработки данных. По сути, здесь пользователям рекомендуется ознакомиться с административным регламентом и с приказом Росстата об утверждении форм статистического наблюдения и самим сделать выводы о сути методологии и изменениях, связанных с переходом от форм Административного регламента к формам федерального статистического наблюдения. Между тем именно в 2018-2019 гг. имели место события (точнее - ситуации), которые вылились в сокращение объемов миграции в 2018 г. и их рост в 2019 г. Отсутствие словесных (и закрепленных на бумаге или на сайте Росстата) пояснений привело к появлению взаимоисключающих выводов о характере миграционных процессов в России ${ }^{20}$. Сокращение миграции в 2018 г. - это своего рода артефакт, вызванный тем, что в административном регламенте по миграционному учету иностранных граждан отсутствовало (было исключено) указание на составление листков учета мигрантов. Ранее листки учета были ведомственной формой МВД (ФМС). Однако с 2018 г. МВД исключило их из своих регламентов, сочтя, что функция сбора статистики не является обязанностью ведомства. Многие регионы перестали собирать для Росстата данные по иностранцам. С 2019 г. Росстат ввел формы отчетности для федерального статистического наблюдения ${ }^{21}$, органы МВД начали передавать сведения для нужд статистики. Возможность возникновения таких ситуаций, конечно, вызывает тревогу. Нарушается логика сбора данных, масштабы недоучета не поддаются оценке (от 10 до 20\%, по нашему мнению). В 2018 г. был зафиксирован самый низкий за последнее десятилетие миграционный прирост, который не смог компенсировать естественной убыли населения России.

Нужно отметить, что в статистическом бюллетене «Численность и миграция населения Российской Федерации» (Росстат 2019) приводится описание методологии сбора и разработки данных ${ }^{22}$. Но и этих пояснений не вполне достаточно, чтобы понять, как перечисленные изменения повлияли на сопоставимость данных, опубликованных в разные годы. Поэтому просто необходимо публиковать на сайте Росстата аналитические материалы, посвященные описанию методологии сбора данных (в ретроспективе) и оценкам их качества. Многим пользователям, особенно не занимающимся постоянным и пристальным наблюдением за изменениями методологии текущего учета, разъяснения специалистов помогут лучше ориентироваться в данных и избежать ошибок при их интерпретации.

\footnotetext{
20 Ломская Т. (2019). Приток мигрантов в Россию достиг исторического минимума. Страна становится менее привлекательной для жителей СНГ. Ведомости, 08 апреля. URL: https://www.vedomosti.ru/economics/articles/2019/04/08/798624-chislo-migrantov-rossii; ТАСС (2019). Приток мигрантов обновил 10-летний максимум, 23 июля. URL: https://tass.ru/obschestvo/6691952

${ }^{21}$ Приказ Росстата от 10 августа 2018 г. №493 "Об утверждении статистического инструментария для организации федерального статистического наблюдения в сфере здравоохранения, за травматизмом на производстве и миграцией населения".

22 «Данные о миграции получены в результате разработки поступающих от территориальных органов Министерства внутренних дел Российской Федерации документов статистического учета прибытий и выбытий. Листки статистического учёта мигрантов составляются при регистрации и снятии с регистрационного учета населения по месту жительства и при регистрации по месту пребывания на срок 9 месяцев и более. Формирование числа выбывших осуществляется автоматически в процессе электронной обработки данных о миграции населения при перемещениях в пределах Российской Федерации, а также по истечении срока пребывания у мигрантов независимо от места прежнего жительства» (Росстат 2019).
} 
Попутно отметим, что переход на новые формы сбора данных от листков статистического учета к формам отчетности, по сути, не изменил общей ситуации (сбора данных на бумаге), но сократилось число переменных по иностранным гражданам. Это лишь узаконило практику, которая уже существовала несколько лет. Начиная с 2019 г., в отчетности, передаваемой из МВД в Росстат, по иностранным гражданам из всего спектра социально-демографических и экономических характеристик предусмотрены только дата рождения, место рождения, пол, гражданство, цель прибытия и профессия. (За исключением гражданства, пола и возраста многие позиции в последние годы не заполняются, очень высок процент «не указавших»).

\section{О ВОЗМОЖНОСТИ КОЛИЧЕСТВЕННОЙ ОЦЕНКИ ПОГРЕШНОСТЕЙ ТЕКУЩЕГО УЧЕТА МИГРАЦИИ}

Можно ли оценить масштабы и характер погрешностей текущего учета (не связанных с недекларированием выбытий и прибытий)? Косвенно это можно будет сделать по итогам предстоящей всероссийской переписи населения, если она состоится ${ }^{23}$ и будет проведена на должном уровне. Сравнение естественного и миграционного прироста за межпереписной период с данными об изменении численности населения России с момента прошлой переписи покажет погрешность учета миграции как международной, так и внутрироссийской.

Кроме того, можно попытаться применить прямой метод измерения. Что имеется в виду? Главное управление по вопросам миграции располагает информационными ресурсами (ГИСМУ, АСАО, ЦБДУИГ) ${ }^{24}$, с помощью которых можно выборочно сделать выгрузки данных и оценить, сколько иностранцев выбывает до окончания срока регистрации, какая часть из них прибывает и регистрируется вновь (в рамках первого срока регистрации). Это дало бы возможность оценить переучет прибытий, недоучет выбытий и объемы повторного счета одних и тех же мигрантов. Следует также, хотя бы в первом приближении, понять, какое число людей оформляют многократные регистрации на короткие сроки, но в совокупности превышающие 9 месяцев.

Мы думаем, что все эти процедуры надо было провести еще до начала введения новой методологии. Это позволило бы специалистам Росстата протестировать допущения, заложенные в новую методологию, и получить некоторые количественные представления о погрешностях в статистике, которые она могла спровоцировать.

В большей степени это применимо к иностранным гражданам, сведения о которых централизованы в ЦБДУИГ. Поскольку единой базы данных о регистрации граждан России нет, но имеются региональные, то в отношении граждан России также можно было выборочно провести проверку для оценки объемов переездов между одним местом

\footnotetext{
${ }^{23}$ Росстат предложил перенести перепись населения на 2021 г. Подробнее на РБК: URL: https://www.rbc.ru/society/02/04/2020/5e8571039a7947beb6ae76ff

${ }^{24}$ ГИСМУ - Государственная информационная система миграционного учета, ЦБДУИГ - Центральный банк данных по учету иностранных граждан, АСАО - Автоматизированная система аналитической отчетности.
} 
пребывания и другим местом пребывания. Конечно, такого рода мероприятия следовало бы выполнить до начала применения новой методологии в масштабах всей страны. Это надо было регулярно делать и впоследствии, проводя своего рода мониторинг ситуации, оценивая, не изменились ли предпочтения мигрантов в сроках регистрации и др.

Отметим, что в советское время, практически с самого начала организации текущего учета и вплоть до 1980-х годов, органы статистики регулярно проводили проверочные мероприятия полноты прописки и выписки населения. Их осуществляли в форме выборочных обходов жилых помещений небольшими комиссиями в составе представителей органов статистки и милиции. Информацию о фактически проживающих в жилом помещении лицах сопоставляли с записями в домовых книгах. По итогам работы комиссий составляли обзоры, которые передавали в центральный аппарат органов статистики. В Государственном архиве можно найти тома дел с материалами такого рода. Результаты проверок становились основой для обращения руководства статистического управления к министру внутренних дел или даже к председателю Совета Министров. Например, 21 октября 1966 г. Министру охраны общественного порядка СССР Н.А. Щелокову было направлено письмо за подписью Начальника ЦСУ СССР В. Старовского ${ }^{25}$, в котором подробно приводились примеры неполноты регистрационного учета населения в паспортных столах. Проверка 1966 г. выявила нарушения практически во всех союзных республиках. Самой распространенной проблемой был недоучет детей в возрасте до 16 лет (доля непрописанных составляла до 40\% этой возрастной группы). Письмо заканчивается рекомендациями органов статистики в адрес органов внутренних дел в следующей формулировке: «В целях обеспечения достоверности данных о передвижении населения ЦСУ СССР считало бы необходимым обязать министерства охраны общественного порядка союзных республик принять следующие меры к улучшению прописки и выписки населения: ...... проводить массово-разъяснительную работу среди населения о правилах прописки и выписки.... систематически проводить инструктивные совещания с работниками паспортных столов, жилищно-эксплуатационных контор, домоуправлений..... о порядке ведения домовых книг, учета детей в них и заполнения адресных листков с отрывными талонами...». В архиве можно найти и копии циркуляров, в которых руководство МВД давало своим подразделениям поручение улучшить ситуацию.

Конечно, в современных условиях речь может идти не о поквартирных обходах, а об использовании информационных ресурсов МВД (ГУВМ) для повышения качества отечественной статистики миграции. И конечно, можно пожелать руководителям нынешнего Росстата восстановить традицию взаимодействия с МВД и более энергично отстаивать право российской статистики отражать реальное положение дел.

\footnotetext{
25 Письмо «О состоянии прописки прибывающего и выписки выбывающего населения органами милиции министерства охраны общественного порядка союзных республик» от 21 октября 1966 г. (сс. 1-6). ГАРФ. Ф.1562. Оп.45. д.2411.
} 


\section{ЗАКЛЮЧИТЕЛЬНЫЕ ЗАМЕЧАНИЯ}

Проведенный анализ показывает, что сейчас российская статистика миграции переживает не лучшие времена. Применяемая методология основана на нескольких весьма существенных допущениях, правомочность которых не подтверждена эмпирическими доказательствами. Они ведут к появлению погрешностей, оценить масштабы которых очень трудно. Погрешности касаются и охвата, и структурных характеристик мигрантов и связаны как с их переучетом, так и недоучетом. Корректировки по «старой методологии» (возвращение к учету миграции только на основании регистрации по месту жительства) невозможны. Многие «временно зарегистрированные» мигранты в силу юридических причин не могут получить регистрацию по месту жительства, но де-факто являются постоянными жителями.

Тем не менее методологию текущего учета миграции (и сам Росстат) трудно критиковать в условиях существующих технологий передачи в Росстат первичной информации из МВД и характера взаимодействия между этими ведомствами. Как показывает практика, трудно согласовать планы и потребности Росстата с планами и возможностями органов по вопросам миграции в связи с их зависимостью от непредсказуемых управленческих и организационных решений высокого уровня и недостаточно сильными позициями Росстата в управленческой системе России. Возможно, одним из решений было бы возвращение Росстату статуса самостоятельного федерального органа исполнительной власти.

В ближайшей перспективе ожидать коренных изменений не приходится из-за того, что МВД не сможет быстро поменять технологию сбора и передачи первичной информации, по крайней мере, это займет время. Конечно, странно обсуждать недостатки, связанные со сбором информации на бумажных носителях, в то время как повсеместно обсуждаются цифровизация и использование инновационных источников данных.

В настоящее время можно предпринять только своего рода паллиативные меры по улучшению качества статистики миграции. Если у Росстата получится организовать совместные с МВД мероприятия по проверке допущений, на которых основана методология текущего учета, то пользователи статистики смогут хотя бы получить ориентиры для корректировки основных показателей текущего учета миграции. Эти мероприятия, разумеется, придется проводить с оглядкой на отмеченные выше проблемы, которые в настоящее время испытывают сами информационные системы ГУВМ.

Определенные надежды на изменения (в более отдаленной перспективе) дает решение о создании Единого информационного ресурса, содержащего сведения о населении. По сути речь идет о регистре населения России, в котором должна отражаться, в том числе, информация о перемене места жительства и места пребывания гражданами России и иностранцами. Помимо сведений о долгосрочных мигрантах там предполагается хранить записи и о многочисленных краткосрочно и временно пребывающих иностранцах. На наш взгляд, это приведет к избыточным затратам ресурсов и трудностям обработки данных. Важнейшей задачей Росстата в отношении Единого ресурса должна стать активная работа с ФНС России, которая будет оператором ресурса, и четкая позиция статистического ведомства по набору данных, которые предполагается получать на его основе. 


\section{ЛИТЕРАТУРА}

Денисенко М.Б. (2012). Эмиграция из России в страны дальнего зарубежья. Если смотреть с другого берега. Демоскоn Weekly, 513-514. URL:

http://www.demoscope.ru/weekly/2012/0513/tema05.php

Мкртчян Н.В. (2003). Возможные причины снижения иммиграции в Россию в 2000-2001 годах. Вопросы статистики, 5, 47-50. URL: http://www.demoscope.ru/weekly/2003/0119/analit02.php

Попов В. (1996). Паспортная система советского крепостничества. Новый мир, 6. URL: http://www.nm1925.ru/Archive/Journal6_1996_6/Content/Publication6_5147/Default.aspx

Росстат (2002). Численность и мигращия населения Российской Федераџии в 2001. Статистический бюллетень. М.

Росстат (2003). Численность и миграџия населения Российской Федерации в 2002. Статистический бюллетень. М.

Росстат (2004). Численность и миграџия населения Российской Федераџии в 2003. Статистический бюллетень. М.

Росстат (2005). Численность и миграџия населения Российской Федераџии в 2004. Статистический бюллетень. М.

Росстат (2006). Численность и миграџия населения Российской Федераџии в 2005. Статистический бюллетень. М.

Росстат (2007). Численность и миграџия населения Российской Федераџии в 2006. Статистический бюллетень. М.

Росстат (2008). Численность и миграџия населения Российской Федераџии в 2007. Статистический бюллетень. М.

Росстат (2009). Численность и миграџия населения Российской Федераџии в 2008. Статистический бюллетень. URL: https://www.gks.ru/bgd/regl/B09_107/Main.htm

Росстат (2010). Численность и миграџия населения Российской Федераџии в 2009. Статистический бюллетень.

URL: https://www.gks.ru/bgd/free/b10_107/Main.htm

Росстат (2011). Численность и миграџия населения Российской Федераџии в 2010. Статистический бюллетень.

URL: https://www.gks.ru/bgd/regl/b11_107/Main.htm

Росстат (2012). Численность и миграџия населения Российской Федераџии в 2011. Статистический бюллетень.

URL: https://www.gks.ru/bgd/regl/b12_107/Main.htm

Росстат (2013). Численность и миграциия населения Российской Федерации в 2012. Статистический бюллетень.

URL: https://www.gks.ru/bgd/regl/b13_107/Main.htm

Росстат (2014). Численность и миграџия населения Российской Федераџиии в 2013. Статистический бюллетень.

URL: https://www.gks.ru/bgd/regl/b14_107/Main.htm 
Росстат (2015). Численность и миграциия населения Российской Федеращии в 2014. Статистический бюллетень.

URL: https://www.gks.ru/bgd/regl/b15_107/Main.htm

Росстат (2016). Численность и миграџия населения Российской Федераџии в 2015. Статистический бюллетень. URL: https://www.gks.ru/bgd/regl/b16_107/Main.htm

Росстат (2017). Численность и мигращия населения Российской Федераџии в 2016. Статистический бюллетень. URL: https://www.gks.ru/bgd/regl/b17_107/Main.htm

Росстат (2018). Численность и миграџия населения Российской Федераџии в 2017. Статистический бюллетень. URL: https://www.gks.ru/bgd/regl/b18_107/Main.htm

Росстат (2019). Численность и миграчия населения Российской Федераиии в 2018. Статистический бюллетень. URL: https://www.gks.ru/bgd/regl/b19_107/Main.htm

Чудиновских О.С. (2009). К вопросу о полноте и качестве данных, передаваемых ФМС России для государственного статистического наблюдения за процессами миграции на постоянное жительство. В Ромодановский К.О., Тюркин М.Л. (Ред.), Миграџия в современной России: состояние, проблемы, тенденции (сс. 293-302). ФМС России. URL: http://www.demoscope.ru/weekly/2009/0389/analit06.php

Чудиновских О.С. (2010). Современное состояние статистики миграции в России: новые возможности и нерешенные проблемы. Вопросы статистики, 6, 8-16.

Чудиновских О.С. (2016). Административная статистика международной миграции: источники, проблемы и ситуация в России. Bопросы статистики, 2, 32-46. DOI: https://doi.org/10.34023/2313-6383-2016-0-2-32-46

Чудиновских О.С. (2019). О пересмотре рекомендаций ООН 1998 г. по статистике и в российском контексте. Вопросы статистики, 26(8), 61-76. DOI: https://doi.org/10.34023/2313-6383-2019-26-8-61-76

Denisenko M.B. (2020). Emigration from the CIS Countries: Old Intentions-New Regularities. In Denisenko M., Strozza S., Light M. (Eds.), Migration from the Newly Independent States. 25 Years after the Collapse of the USSR (pp. 81-123). Springer Nature Switzerland AG. DOI: https://link.springer.com/chapter/10.1007\%2F978-3-030-36075-7_5

Hugo G. (2013). What we know about circular migration and enhanced mobility. Migration Policy Institute, 7, 1-10. URL: https://www.migrationpolicy.org/research/what-we-knowabout-circular-migration-and-enhanced-mobility

United Nations (1998). Recommendations on Statistics of International Migration. Revision 1. New York. URL: https://unstats.un.org/unsd/demographic-social/standards-andmethods/?Desc=International+Migration

United Nations (2016). Defining and Measuring Circular Migration. New York and Geneva. URL: https://www.unece.org/index.php?id=44717) 


\title{
ON THE QUALITY OF THE FEDERAL STATISTICAL OBSERVATION OF MIGRATION PROCESSES
}

\author{
OLGA CHUDINOVSKIKH, ANASTASIA STEPANOVA
}

\begin{abstract}
The article deals with the main problems inherent in the methodology of statistical observation of long-term migration flows introduced by Rosstat in 2011. The changes in the methodology of migration flow statistics, the reasons for them and their possible impact on the volume and structure of flows within the post-Soviet period are described in historical retrospective. The article describes in detail the situation that has developed in Russian migration statistics in recent years, in which statistics have begun to consider as migrants not only persons registered at their place of residence, but also those who were registered at a place of temporary stay for a period of 9 months and more. Changes in the criteria of migrant status have led to significant shifts in the indicators of international and internal migration. The volume of registered migration has increased and the structural characteristics of flows have changed, primarily in terms of directions of migration and citizenship of migrants. The article focuses on international migration statistics, since the consequences of using the new data collection principles were most pronounced in this segment of statistics.

It is concluded that the modern methodology of data collection is based on a number of controversial assumptions, the validity of which has not been verified empirically. As a possible interim solution it is proposed to establish cooperation between Rosstat and migration authorities to jointly conduct selective inspection of information possessed by the Ministry of Internal Affairs, in order to verify its validity and assess the extent of errors that the new migrant accounting methodology may cause.
\end{abstract}

Key words: migration data collection, registration at the place of residence and place of stay, migration statistics, citizenship.

Olga ChudinovskikH (migrstat@yandex.ru), Lomonosov Moscow State University, Russia.

AnASTASia STEPanova (stepanova.anastasia@gmail.com), Lomonosov Moscow State University, Russia.

DATE RECEIVED: JANUARY 2020.

\section{REFERENCES}

Chudinovskikh O.S. (2009). K voprosu o polnote i kachestve dannykh, peredavayemykh FMS Rossii dlya gosudarstvennogo statisticheskogo nablyudeniya za protsessami migratsii na postoyannoye zhitel'stvo [On the issue of completeness and quality of data transmitted by the Federal migration service of Russia for state statistical monitoring of migration processes for permanent residence]. In Romodanovskiy K., Tyurkin M. (Eds.), Migratsiya v sovremennoy Rossii: sostoyaniye, problemy, tendentsii [Migration in modern Russia: status, problems, trends] (pp. 293-302). FMS Rossii. (In Russ.). URL: http://www.demoscope.ru/weekly/2009/0389/analit06.php

Chudinovskikh O.S. (2010). Sovremennoye sostoyaniye statistiki migratsii v Rossii: novyye vozmozhnosti i nereshennyye problemy [Current state of migration statistics in Russia: new opportunities and unresolved problems]. Voprosy statistiki, 6, 8-16. (In Russ.).

Chudinovskikh O.S. (2016). Administrativnaya statistika mezhdunarodnoy migratsii: istochniki, problemy i situatsiya v Rossii [Administrative statistics of international migration: sources, 
problems and situation in Russia]. Voprosy statistiki, 2, 32-46. (In Russ.). DOI: https://doi.org/10.34023/2313-6383-2016-0-2-32-46

Chudinovskikh O.S. (2019). O peresmotre rekomendatsiy OON 1998 g. po statistike i v rossiyskom kontekste [On Revision of the UN Recommendations on Statistics of Migration (1998) and the Russian Context]. Voprosy statistiki, 26(8), 61-76. (In Russ.). DOI:https://doi.org/10.34023/2313-6383-2019-26-8-61-76

Denisenko M. (2012). Emigratsiya iz Rossii v strany dal'nego zarubezh'ya. Esli smotret' s drugogo berega [Emigration from Russia to foreign countries. If you look from the other side]. Demoscope Weekly, 513-514 (In Russ.). URL: http://www.demoscope.ru/weekly/2012/0513/tema05.php

Denisenko M. (2020). Emigration from the CIS Countries: Old Intentions-New Regularities. In Denisenko M., Strozza S., Light M. (Eds.), Migration from the Newly Independent States. 25 Years after the Collapse of the USSR (pp. 81-123). Springer Nature Switzerland AG. DOI: https://link.springer.com/chapter/10.1007\%2F978-3-030-36075-7_5

Hugo G. (2013). What we know about circular migration and enhanced mobility. Migration Policy Institute, 7, 1-10. URL: https://www.migrationpolicy.org/research/what-we-knowabout-circular-migration-and-enhanced-mobility

Mkrtchyan N.V. (2003). Vozmozhnyye prichiny snizheniya immigratsii v Rossiyu v 2000-2001 godakh [Possible reasons for the decline in immigration to Russia in 2000-2001]. Voprosy statistiki, 5, 47-50. (In Russ.). URL: http://www.demoscope.ru/weekly/2003/0119/analit02.php

Popov V. (1996). Pasportnaya sistema sovetskogo krepostnichestva [The passport system of the Soviet serfdom]. Novyy mir, 6. (In Russ.). URL: http://www.nm1925.ru/Archive/Journal6_1996_6/Content/Publication6_5147/Default.aspx

Rosstat (2002). Chislennost' i migratsiya naseleniya Rossiyskoy Federatsii v 2001 [The size and migration of population of the Russian Federation in 2001]. Statisticheskiy sbornik [Statistical bulletin]. Moscow. (In Russ.).

Rosstat (2003). Chislennost' i migratsiya naseleniya Rossiyskoy Federatsii v 2002 [The size and migration of population of the Russian Federation in 2002]. Statisticheskiy sbornik [Statistical bulletin]. Moscow. (In Russ.).

Rosstat (2004). Chislennost' i migratsiya naseleniya Rossiyskoy Federatsii v 2003 [The size and migration of population of the Russian Federation in 2003]. Statisticheskiy sbornik [Statistical bulletin]. Moscow. (In Russ.).

Rosstat (2005). Chislennost' i migratsiya naseleniya Rossiyskoy Federatsii v 2004 [The size and migration of population of the Russian Federation in 2004]. Statisticheskiy sbornik [Statistical bulletin]. Moscow. (In Russ.).

Rosstat (2006). Chislennost' i migratsiya naseleniya Rossiyskoy Federatsii v 2005 [The size and migration of population of the Russian Federation in 2005]. Statisticheskiy sbornik [Statistical bulletin]. Moscow. (In Russ.).

Rosstat (2007). Chislennost' i migratsiya naseleniya Rossiyskoy Federatsii v 2006 [The size and migration of population of the Russian Federation in 2006]. Statisticheskiy sbornik [Statistical bulletin]. Moscow. (In Russ.).

Rosstat (2008). Chislennost' i migratsiya naseleniya Rossiyskoy Federatsii v 2007 [The size and migration of population of the Russian Federation in 2007]. Statisticheskiy sbornik [Statistical bulletin]. Moscow. (In Russ.). 
Rosstat (2009). Chislennost' i migratsiya naseleniya Rossiyskoy Federatsii v 2008 [The size and migration of population of the Russian Federation in 2008]. Statisticheskiy sbornik [Statistical bulletin]. (In Russ.). URL: https://www.gks.ru/bgd/regl/B09_107/Main.htm

Rosstat (2010). Chislennost' i migratsiya naseleniya Rossiyskoy Federatsii v 2009 [The size and migration of population of the Russian Federation in 2009]. Statisticheskiy sbornik [Statistical bulletin]. (In Russ.). URL: https://www.gks.ru/bgd/free/b10_107/Main.htm

Rosstat (2011). Chislennost' i migratsiya naseleniya Rossiyskoy Federatsii v 2010 [The size and migration of population of the Russian Federation in 2010]. Statisticheskiy sbornik [Statistical bulletin]. (In Russ.). URL: https://www.gks.ru/bgd/regl/b11_107/Main.htm

Rosstat (2012). Chislennost' i migratsiya naseleniya Rossiyskoy Federatsii v 2011 [The size and migration of population of the Russian Federation in 2011]. Statisticheskiy sbornik [Statistical bulletin]. (In Russ.). https://www.gks.ru/bgd/regl/b12_107/Main.htm

Rosstat (2013). Chislennost' i migratsiya naseleniya Rossiyskoy Federatsii v 2012 [The size and migration of population of the Russian Federation in 2012]. Statisticheskiy sbornik [Statistical bulletin]. (In Russ.). URL: https://www.gks.ru/bgd/regl/b13_107/Main.htm

Rosstat (2014). Chislennost' i migratsiya naseleniya Rossiyskoy Federatsii v 2013 [The size and migration of population of the Russian Federation in 2013]. Statisticheskiy sbornik [Statistical bulletin]. (In Russ.). URL: https://www.gks.ru/bgd/regl/b14_107/Main.htm

Rosstat (2015). Chislennost' i migratsiya naseleniya Rossiyskoy Federatsii v 2014 [The size and migration of population of the Russian Federation in 2014]. Statisticheskiy sbornik [Statistical bulletin]. (In Russ.). URL: https://www.gks.ru/bgd/regl/b15_107/Main.htm

Rosstat (2016). Chislennost' i migratsiya naseleniya Rossiyskoy Federatsii v 2015 [The size and migration of population of the Russian Federation in 2015]. Statisticheskiy sbornik [Statistical bulletin]. M (In Russ.). URL: https://www.gks.ru/bgd/regl/b16_107/Main.htm

Rosstat (2017). Chislennost' i migratsiya naseleniya Rossiyskoy Federatsii v 2016 [The size and migration of population of the Russian Federation in 2016]. Statisticheskiy sbornik [Statistical bulletin]. (In Russ.). URL: https://www.gks.ru/bgd/regl/b17_107/Main.htm

Rosstat (2018). Chislennost' i migratsiya naseleniya Rossiyskoy Federatsii v 2017 [The size and migration of population of the Russian Federation in 2017]. Statisticheskiy sbornik [Statistical bulletin]. Mos (In Russ.). URL: https://www.gks.ru/bgd/regl/b18_107/Main.htm

Rosstat (2019). Chislennost' i migratsiya naseleniya Rossiyskoy Federatsii v 2018 [The size and migration of population of the Russian Federation in 2018]. Statisticheskiy sbornik [Statistical bulletin]. (In Russ.). URL: https://www.gks.ru/bgd/regl/b19_107/Main.htm

United Nations (1998). Recommendations on Statistics of International Migration. Revision 1. New York. URL: https://unstats.un.org/unsd/demographic-social/standards-andmethods/?Desc=International+Migration

United Nations (2016). Defining and Measuring Circular Migration. New York and Geneva. URL: https://www.unece.org/index.php?id=44717) 